\title{
Imaging-genetics in autism spectrum disorder: advances, translational impact, and future directions
}

\author{
Stephanie H. Ameis ${ }^{1 *}$ and Peter Szatmari ${ }^{2}$ \\ ' Department of Psychiatry, The Hospital for Sick Children, University of Toronto, Toronto, ON, Canada \\ ${ }^{2}$ Department of Psychiatry and Behavioural Neurosciences, Offord Centre for Child Studies, McMaster University, Hamilton, ON, Canada
}

\section{Edited by:}

Aristotle Voineskos, Centre for Addiction and Mental Health, Canada

Reviewed by:

Paul Croarkin, Mayo Clinic, USA

Peter Enticott, Monash University,

Australia

\section{*Correspondence:}

Stephanie H. Ameis, Department of Psychiatry, The Hospital for Sick

Children, University of Toronto, 555 University Avenue, Toronto, ON,

Canada M5G 1 X8.

e-mail: stephanie.ameis@utoronto.ca
Autism Spectrum Disorder (ASD) refers to a group of heterogeneous neurodevelopmental disorders that are unified by impairments in reciprocal social communication and a pattern of inflexible behaviors. Recent genetic advances have resolved some of the complexity of the genetic architecture underlying ASD by identifying several genetic variants that contribute to the disorder. Different etiological pathways associated with ASD may converge through effects on common molecular mechanisms, such as synaptogenesis, neuronal motility, and axonal guidance. Recently, with more sophisticated techniques, neuroimaging, and neuropathological studies have provided some consistency of evidence that altered structure, activity, and connectivity within complex neural networks is present in ASD, compared to typically developing children. The imaging-genetics approach promises to help bridge the gap between genetic variation, resultant biological effects on the brain, and production of complex neuropsychiatric symptoms. Here, we review recent findings from the developing field of imaging-genetics applied to ASD. Studies to date have indicated that relevant risk genes are associated with alterations in circuits that mediate socioemotional, visuo-spatial, and language processing. Longitudinal studies ideally focused on early development, in conjunction with investigation for gene-gene, and gene-environment interactions may move the promise of imaging-genetics in ASD closer to the clinical domain.

Keywords: autism spectrum disorder, neuroimaging, genetics, imaging-genetics, neurodevelopment

\section{INTRODUCTION}

The Autism Spectrum Disorder (ASD) refers to a group of heterogeneous neurodevelopmental disorders that are unified by impairments in reciprocal social communication, and a pattern of inflexible behaviors (First, 2000). ASD affects roughly 1 in 150 people, and is four times as common in males than in females (Fombonne, 2001). The severity of ASD impairment ranges across the spectrum from mild to profound, with approximately $40 \%$ of affected individuals exhibiting significant cognitive deficit (Bauman, 2010). This complex disorder was first described in the early 1940s, in separate reports by Leo Kanner and Hans Asperger, describing children with characteristic symptoms of ASD, with or without language impairments (Kanner, 1971; Szatmari, 2000). These seminal reports laid the foundation for diagnostic distinctions between autistic and Asperger's disorder, which the field is now moving away from as the search for biological markers of the complex heterogeneity that exists across the autism spectrum continues (Szatmari, 2011). By the late 1970s, the substantial role that genetic factors play in conferring risk for ASD was established (Folstein and Rutter, 1977). Over the past decade, technical advances have led to major research discoveries in ASD, moving the field closer to understanding the complex etiological mechanisms that contribute to the disorder. Genetic studies have highlighted the substantial heterogeneity of the genetic architecture underlying ASD (Geschwind, 2011). Functional analyses have indicated that several ASD associated gene protein products interact in pathways involved in neuronal architecture, synapse formation, and function (State and Levitt, 2011; Marshall and Scherer, 2012). Post-mortem work has highlighted evidence for altered brain development in ASD that affects neuron number, axon density, and the formation of neural circuits (Zikopoulos and Barbas, 2010; Courchesne et al., 2011; Voineagu et al., 2011). Neuroimaging studies in ASD have provided in vivo evidence of: (i) altered cortical and subcortical brain development (Schumann et al., 2010; Nordahl et al., 2012), (ii) impaired integrity among white matter connections (Barnea-Goraly et al., 2010; Ameis et al., 2011; Shukla et al., 2011), and (iii) atypical network activity and connectivity within frontal and temporal circuits, important for socio-emotional, and language function, in affected individuals (Just et al., 2004; Wicker et al., 2008; Di Martino et al., 2009). Taken together, converging lines of evidence point to an etiological role for biological pathways that impact on synapse structure and transmission at the genetic level and fronto-temporal network structure and connectivity at the circuit-based level. A detailed understanding of just how genetic variation translates into alterations within specific circuits is now needed for therapeutic advancement in ASD. The imaging-genetics strategy has proven to be a powerful tool for studying complex neuropsychiatric disorders (Meyer-Lindenberg and Weinberger, 2006). Studies using this method have begun to bridge the gap between genetic variation, neural mechanisms, and psychiatric symptoms. In the present article, we review preliminary findings from imaging-genetics research in ASD, and discuss 
optimal avenues for leveraging this method to advance the field further. We begin with a brief narrative summary of relevant genetics and brain findings in ASD.

\section{SUMMARY OF THE GENETICS OF ASD}

The ability to sequence genetic information, and perform genomewide scanning in large population studies has provided valuable and novel insights into some of the etiological complexity underlying ASD. In approximately $10 \%$ of individuals with ASD, the disorder can be attributed to known single-gene mutation syndromes, such as fragile $\mathrm{X}$ syndrome and tuberous sclerosis complex, and identified metabolic conditions (Schaaf and Zoghbi, 2011). Genome-wide screening for copy number variants (CNVs), describing DNA segments ( $>1 \mathrm{~kb}$ ) with varying numbers of copies between individuals, has implicated increased rates of de novo CNVs in ASD (i.e., 6\% in simplex and multiplex ASD families versus $\sim 1 \%$ in the general population; Pinto et al., 2010). Relevant de novo genomic imbalances can now be detected in $7-10 \%$ of idiopathic autism cases (Schaaf and Zoghbi, 2011). Nevertheless, no single risk locus has been able to account for more than $\sim 1 \%$ of affected individuals. Further, recent CNV analyses have estimated that there are at minimum hundreds of target loci where CNV mutations can lead to ASD (Levy et al., 2011). Although genome-wide association studies (GWAS) have implicated a small number of common genetic variants that confer risk for ASD [i.e., cadherin 9 and 10 (Wang et al., 2009), semaphorin-5A (SEMA5A; Weiss et al., 2009), contactin-associated protein-like 2 (CNTNAP2; Arking et al., 2008), the absence of successful replication between studies and small effect sizes found for identified risk variants, has diminished previous estimation of the role that common genetic variation plays in causing autism (Geschwind, 2011). However, given the substantial genetic heterogeneity in ASD, sample sizes of current GWAS may still be too small to detect common variants of small effect. In recent reviews of the genetics literature, a loading threshold for ASD has been proposed, such that some rare de novo CNVs may have large (causal) impact on ASD susceptibility, while CNVs with smaller effects may act in concert with other rare or common genetic or environmental factors, to push the genetic load over the threshold for phenotypic expression (Marshall and Scherer, 2012). Diverse genetic factors may then contribute to the overlapping ASD phenotype through convergent influence on common biological pathways. Functional analyses of ASD risk genes have highlighted the importance of gene pathways involved in: synaptogenesis, axon guidance, and neuronal motility (Geschwind, 2011; Gilman et al., 2011; Marshall and Scherer, 2012). However, inconsistencies between these functional analyses indicate that knowledge of common etiological pathways contributing to ASD remains preliminary.

\section{SUMMARY OF BRAIN FINDINGS IN ASD}

As with genetics research, technical advances in non-invasive neuroimaging and post-mortem analysis over the last decade have led to an improved understanding of the neural correlates of idiopathic ASD. Post-mortem and neuroimaging studies now point to altered brain development in ASD, involving disrupted structure and function within fronto-temporal circuits that mediate socio-communicative behavior. For example, a recent study demonstrated a $67 \%$ increase in the number of neurons within the prefrontal cortex in ASD brain, pointing to excess prenatal neural proliferation, decreased prenatal or postnatal apoptosis, or both (Courchesne et al., 2011). Another report demonstrated altered axon density and myelin impairment in fronto-limbic white matter in post-mortem ASD (Zikopoulos and Barbas, 2010). Other research has indicated that genes that help to distinguish frontal and temporal cortex in typical brain development are diminished in ASD brain (Voineagu et al., 2011). Preliminary findings have also indicated that gene expression changes in ASD brain may involve gene systems that regulate neuronal synapses (Voineagu et al., 2011). The initial results from longitudinal magnetic resonance imaging (MRI) research have provided in vivo evidence that abnormal brain development in ASD involves increased frontal and temporal gray and white matter volume, and enlarged amygdala volume in ASD children between 2 and 5 years of age, compared to controls (Schumann et al., 2010; Nordahl et al., 2012). While generalized brain overgrowth may likely characterize early childhood ASD, MRI studies have found evidence of more localized volumetric abnormalities within frontal white matter, and frontal and temporal gray matter regions in older children, adolescents and adults with ASD (Herbert et al., 2003; Hyde et al., 2010). A recent longitudinal diffusion tensor imaging (DTI) study that reported on the developmental trajectory of white matter microstructure in infant siblings of children with ASD (at highrisk for the disorder) has provided in vivo evidence of an evolving pattern of brain disruption in early childhood ASD. In this study, infant siblings diagnosed with ASD at 24 months of age exhibited increased fractional anisotropy (an index of microstructural white matter integrity) across several interhemispheric and association white matter pathways at 6 months of age, and altered white matter development between 6 and 24 months of age, when compared to matched high-risk siblings without an ASD diagnosis at 24 months (Wolff et al., 2012). In conjunction with DTI studies of older children, and adults with ASD, these findings contribute to strong evidence for a disruption in the normal development of white matter tract microstructure mediating longrange brain connectivity (Pugliese et al., 2009; Kumar et al., 2010; Ameis et al., 2011; Radua et al., 2011). Functional neuroimaging [i.e., functional MRI (fMRI) and positron emission tomography $(\mathrm{PET})]$ results in ASD have varied depending on methods and task paradigms used (Schultz et al., 2000; Pierce et al., 2001, 2004; Hadjikhani et al., 2004). However, a recent meta-analysis of fMRI and PET studies examining children, adolescents and adults with ASD, compared to controls, provides helpful insights into overall trends across this literature. This meta-analysis demonstrated that individuals with ASD exhibit: (i) reduced probability for activation of higher-order social (i.e., amygdala, cingulate, fusiform gyrus, insula) and executive processing (i.e., dorsolateral prefrontal cortex) structures and (ii) increased activation of lower-order structures that mediate primary motor and sensory processing during complex socio-emotional and executive task performance (Di Martino et al., 2009). Other functional imaging work measuring correlated activity between regions, as a surrogate index of network connectivity, has consistently implicated reduced functional connectivity in ASD across neural networks that mediate complex tasks (Just et al., 2004, 2007; Kana et al., 2006; Kennedy 
and Courchesne, 2008; Wicker et al., 2008). Further, preliminary work using transcranial magnetic stimulation, a method enabling stimulation of the cortex using magnetic pulses, has implicated impaired cortical inhibition in young adults with ASD, consistent with reduced $\gamma$-aminobutyric acid (GABA) receptor protein expression found in post-mortem autistic brain tissue (Fatemi et al., 2009). Impaired cortical inhibition may be one factor that contributes to altered (and variable) brain activation in ASD (Enticott et al., 2010). Thus, while post-mortem data has pointed to an early event that disrupts development of neurons and their connections, neuroimaging findings have provided in vivo evidence for abnormal frontal and temporal brain growth, altered white matter tract development, abnormal activation, and reduced integration of complex neural circuits. Although brain alterations in ASD are widespread, findings that implicate abnormal frontal and temporal circuitry recurs throughout the literature. Early validation of theories positing that brain-based phenotypes in ASD likely evolve across development (Belmonte et al., 2004), based on the results of the first developmental studies published in ASD (Wolff et al., 2012), has emphasized the critical need for longitudinal research in a disorder where abnormal development is essential to the diagnosis.

\section{IMAGING-GENETICS REVIEW IN ASD}

In the following sections, we present our review of imaginggenetics research in ASD. A sensitive search strategy in three relevant article databases (MEDLINE, Embase, and PsycINFO) using the OvidSP database interface was completed to find English language references on the topic of neuroimaging research of genes associated with ASD. Our search terms included the database subject headings for the concepts of pervasive developmental disorders, genetics, and magnetic resonance imaging. The OvidSP interface multipurpose search command (.mp.) was used to search for additional search terms derived from the "used for" section of the database subject headings; unlimited truncation symbol “*” was applied to capture variation in suffix endings when appropriate. Relevant articles retrieved from our search included: (i) 11 imaging-genetic studies that have examined the brain effects of common genetic variants associated with idiopathic ASD, and (ii) 34 neuroimaging studies focused on investigating the neural alterations associated with syndromic autism. Here, we provide a comprehensive review of those studies that have examined genes associated with idiopathic ASD based on GWAS, and genome-wide CNV studies (see Table 1); we include brief discussion of studies that have examined common variants in genes that code for signaling proteins in ASD as work in this area could have important therapeutic implications. Although a full review of neuroimaging studies that have focused on genetic syndromes associated with autism is beyond the scope of this article, we present a number of select examples from this literature. These include studies describing brain structure in genetic syndromes that have high rates of ASD (i.e., fragile X syndrome, 22q.11.2 deletion syndrome, tuberous sclerosis complex) highlighting the value of utilizing the neuroimaging approach to search for common intermediate phenotypes. Here, we chose to include studies comparing syndromic and idiopathic autism groups to a relevant control group; if no such study design was available in the current literature, articles comparing a genetic syndrome group, with or without co-morbid autism, were included.

The majority of imaging-genetics studies relevant to ASD are designed in accordance with the intermediate phenotype concept applied to neuropsychiatry. The intermediate phenotype concept assumes that genes do not code for psychopathology but mediate risk for symptom expression through their effects on relevant neural systems. Individuals carrying risk alleles for a given disorder would therefore exhibit effects in the brain, even in the absence of clinical symptoms (Meyer-Lindenberg and Weinberger, 2006). Based on this premise, intermediate "brain-based" phenotypes associated with common genetic variants can be studied in healthy populations, an advantageous design for collecting large samples and minimizing confounds associated with illness. Research that has utilized the intermediate phenotype approach to characterize the neural effects of ASD-implicated genes can be broadly organized into studies of: (i) common variants within genes important for cell-cell interactions, and (ii) variation in genes encoding signaling proteins (i.e., neuropeptides, neurotransmitters, and neurotrophins).

\section{GENES AFFECTING CELL-CELL INTERACTION}

A small number of imaging-genetics studies have begun to characterize the neural effects of neurexin superfamily gene variants, implicated in ASD. The neurexins (Nrxn) are largely presynaptic proteins that form a trans-synaptic complex with postsynaptic neuroligins (Nlgn). Deletions affecting the Nrxn1-a gene (1.1 Mb region, chromosome $2 \mathrm{p} 16.3$ ) have been repeatedly observed in ASD (Sebat et al., 2007; Szatmari et al., 2007; Kim et al., 2008; Marshall et al., 2008; Yan et al., 2008) and schizophrenia (Walsh et al., 2008; Kirov et al., 2009; Rujescu et al., 2009). Mutations have also been found in Nlgn3 (Xq13.1) and Nlgn4X (Xp22.32p22.31) in ASD (Jamain et al., 2003; Laumonnier et al., 2004; Yan et al., 2005). Other CNVs found to affect the Shank family of scaffolding proteins (Shank 1-3) in ASD (Pinto et al., 2010), which bind to the Nlgns, provide further evidence that disruption to the $N r \times n / N l g n / S h a n k$ synaptic complex confers risk for the disorder. Animal models point to the presence of alterations in excitatory synaptic neurotransmission, and excitatory/inhibitory balance in $a-N r x n$ knock out (KO) mice, as well as mice featuring Nlgn and Shank3 protein disruption (Sudhof, 2008; Etherton et al., 2009; Bangash et al., 2011). In these mouse models, phenotypic traits analogous to autism (i.e., repetitive grooming, and impaired social interactions) have also been found. Further, a microdeletion syndrome affecting chromosome 22q13.3 resulting in haploinsufficiency of Shank3 leads to a developmental phenotype that includes autistic symptoms (Philippe et al., 2008). A phenotypic characterization study of eight children (5-8 years, three girls) with 22q13.3 microdeletion affecting Shank3, described slowed motor and language development, repetitive behaviors, ADHD symptoms, mild to severe delay in cognitive milestones and significant social and communication impairments in affected children. Neuroimaging abnormalities found in 22q13.3 microdeletion syndrome included: MRI-measured thinning of the corpus callosum, and temporal hypoperfusion, measured using PET (Philippe et al., 2008). Of the Nrxn/Nlgn/Shank complex genes, the neural effects associated with common variation in the Nrxnl gene has been 
Table 1 | Imaging-genetics studies using the intermediate phenotype approach to examine the neural effects of ASD-related risk genes.

\begin{tabular}{|c|c|c|c|c|c|}
\hline Study & $\begin{array}{l}\text { Participants (F:M): } \\
\text { mean } \pm \text { SD }\end{array}$ & Gene & Imaging method & $\begin{array}{l}\text { Gene variant studied: } \\
\text { genotype group ( } n)\end{array}$ & Key results \\
\hline \multicolumn{6}{|c|}{ NEUREXIN SUPERFAMILY GENES } \\
\hline \multirow[t]{2}{*}{ Tan et al. (2010) } & $314 \mathrm{HCs}$ & CNTNAP2 & $\begin{array}{l}\text { MRI (VBM): GMMMM } \\
\text { volume }\end{array}$ & rs779475: T/T; T/A, A/A & $\begin{array}{l}\text { rs } 779475 T / T: ~ \downarrow \text { volume in cerebellum, } \\
\text { fusiform gyrus, posterior occipital, } \\
\text { frontal pole, cingulum, thalamic } \\
\text { radiations, IFOF }\end{array}$ \\
\hline & & & $\begin{array}{l}\text { DTI: voxel-wise FA } \\
\text { analysis }\end{array}$ & & $\begin{array}{l}\text { Sex-specific associations with } \\
\text { rs } 779475 T / T: \downarrow F A \text { in right IFOF in } \\
\text { males, } \downarrow F A \text { in right thalamic radiation in } \\
\text { females }\end{array}$ \\
\hline & $\begin{array}{l}\text { Sample II - 39HC } \\
\text { children: } \\
(16 \mathrm{~F}: 23 \mathrm{M})\end{array}$ & & fcMRI & $\begin{array}{l}\text { Sample I: C/C,T/C (9); } \\
\text { T/T(23) } \\
\text { Sample II: C/C,T/C (29); } \\
\text { T/T (10) }\end{array}$ & $\begin{array}{l}\text { Sample II (fcMRI)- rs } 2710102 \mathrm{C} \text { : } \\
\downarrow \text { long-range (mPFC to } \\
\text { occipital/temporal cortex) } \uparrow \text { short-range } \\
\text { (mPFC to frontal cortex) connectivity }\end{array}$ \\
\hline $\begin{array}{l}\text { Whalley et al. } \\
\text { (2011) }\end{array}$ & $\begin{array}{l}66 \mathrm{HCs} \\
(35 \mathrm{~F}: 31 \mathrm{M}): \sim 20 \pm 2\end{array}$ & CNTNAP2 & $\begin{array}{l}\text { fMRI: verbal fluency } \\
\text { task }\end{array}$ & $\begin{array}{l}\mathrm{rs} 2710102: \mathrm{C} / \mathrm{C}(n=16) \\
\mathrm{C} / \mathrm{T}, \mathrm{T} / \mathrm{T}(n=50)\end{array}$ & On verbal fluency: \\
\hline & & & & $\begin{array}{l}\mathrm{rs} 779745: \mathrm{T} / \mathrm{T}(n=8) \\
\mathrm{T} / \mathrm{A}, \mathrm{A} / \mathrm{A}(n=57)\end{array}$ & $\begin{array}{l}\uparrow R \text { Right IFG activity in rs } 2710102 \mathrm{C} / \mathrm{C} \\
\uparrow \text { Right MTG activity in rs } 779475 \mathrm{~T} / \mathrm{T}\end{array}$ \\
\hline Inoue et al. (2010) & $\begin{array}{l}208 \mathrm{HCs} \\
(143 \mathrm{M}: 65 \mathrm{~F}): \\
33.9 \pm 11.6\end{array}$ & OXTR & $\begin{array}{l}\text { MRI: ROI volume: } \\
\text { amygdala, hippocampus }\end{array}$ & $\begin{array}{l}\text { rs2254298: } A / A(77) \\
A / G(85) ; G / G(44)\end{array}$ & $\uparrow$ Amygdala volume in rs $2254298 \mathrm{~A}$ \\
\hline $\begin{array}{l}\text { Furman et al. } \\
\text { (2011) }\end{array}$ & $\begin{array}{l}51 \text { female HCs: } \\
13 \pm 1.5\end{array}$ & OXTR & $\begin{array}{l}\text { MRI (VBM): GMMM } \\
\text { volume + ROI volume: } \\
\text { amygdala }\end{array}$ & $\begin{array}{l}\text { rs2254298: A/G (16); } \\
\text { G/G (35) }\end{array}$ & $\begin{array}{l}\uparrow \mathrm{GM} \text { volume in rs2254298G/G } \\
\downarrow \text { Amygdala volume in rs2254298G/G }\end{array}$ \\
\hline $\begin{array}{l}\text { Meyer- } \\
\text { Lindenberg et al. } \\
(2011)\end{array}$ & $\begin{array}{l}258 \mathrm{HCs} \\
(149 \mathrm{~F}: 109 \mathrm{M}): \\
31.5 \pm 9.6\end{array}$ & AVPR1A & $\begin{array}{l}\text { fMRI: face processing } \\
\text { task }\end{array}$ & $\begin{array}{l}\text { (Select RS1, RS3 } \\
\text { ASD-risk alleles): RS3 } \\
\text { 334bp (57); RS1 } 312 \text { bp } \\
\text { (39); RS1 320bp (54) }\end{array}$ & $\begin{array}{l}\uparrow \text { Left amygdala activity in RS3 334bp } \\
\uparrow \text { Left amygdala activity in RS1 } 312 \text { bp } \\
\text { versus 320bp } \\
\downarrow \text { Left amygdala activity in RS1 320bp }\end{array}$ \\
\hline
\end{tabular}

SD, standard deviation; HCS, healthy controls; F, females; M, males; CNTNAP2: contactin-associated-protein like 2; OXTR, oxytocin receptor gene; AVPR1A, arginine vasopressor receptor $1 A$ gene; MRI, magnetic resonance imaging; sMRI, structural MRI; VBM, voxel-based morphometry; DTI, diffusion tensor imaging; FA, fractional anisotropy; $F M R I$, functional MRI; fCMRI, functional connectivity MRI; GM, grey matter; WM, white matter; TPQ, tridimensional personality questionnaire; ROI, region of interest; IFOF, inferior-fronto-occipital fasciculus; MPFC, medial prefrontal cortex; IFG, inferior frontal gyrus; MTG, medial temporal gyrus. 
studied in a healthy sample. Voineskos and colleagues examined structural brain differences associated with $N r \times n 1$ variants (rs1045881C and rs858932G) in a sample of 53 healthy controls. Compared to non-risk homozygotes, healthy individuals who were homozygous for the rs1045881C risk allele exhibited reduced frontal lobe white matter volume, thalamic volume (Voineskos et al., 2011), and slower finger-tapping speed that correlated positively with reduced frontal white matter volume. An in silico analysis of the rs $1045881 \mathrm{C}$ single nucleotide polymorphism (SNP) indicated that this $3^{\prime}$ untranslated region variant creates a microRNA binding site. These in silico results suggest that common rs1045881 variation could exert structural effects on frontal lobe white matter through altered Nrxn1 expression.

The CNTNAP2 gene (2.3 Mb region, chromosome $7 q 35-36$ ) is another member of the neurexin superfamily, associated with autism (Alarcon et al., 2008; Arking et al., 2008; Bakkaloglu et al., 2008), and specific language impairment (Vernes et al., 2008). Roughly 70\% of Old Order Amish children with cortical dysplasiafocal epilepsy syndrome, secondary to a recessive nonsense CNTNAP2 mutation, exhibit ASD (Strauss et al., 2006). The CNTNAP2 gene encodes a neural transmembrane protein, involved in neuronal-glial interactions, and in clustering $\mathrm{K}^{+}$channels in myelinated axons (Strauss et al., 2006; Penagarikano et al., 2011). A recent study demonstrated that CNTNAP2 KO mice exhibit an ASD-like phenotype that includes: seizures, hyperactivity, sensory alterations, perseveration, and reduced ultrasonic vocalizations and social interactions, when compared to wild-type mice (Penagarikano et al., 2011). Further, CNTNAP2 KO mouse brain findings have implicated the importance of CNTNAP2 for normal neural migration, GABAergic inhibitory interneuron regulation, and synchronous neuronal firing (Penagarikano et al., 2011). In humans, CNTNAP2 expression is enriched in frontal, temporal, striatal, and thalamic regions (Alarcon et al., 2008). To date, three imaging-genetics studies have examined the neural effects associated with common variants in CNTNAP2. In the largest of these studies, Tan and colleagues used structural MRI and DTI to examine brain effects associated with the CNTNAP2 rs779475 SNP in 314 healthy individuals. In this study, risk allele homozygotes (rs779475 T/T) exhibited reduced gray matter volume in cerebellum, frontal, and occipital lobes, and reduced white matter volume in posterior thalamic radiations, right rostral cingulum bundle, and caudal portions of the right inferior-fronto-occipital fasciculus, compared to a combined group of rs779475T heterozygotes and non-risk homozygotes (A/A; Tan et al., 2010). More dramatic reductions in right frontal gray matter volume were found in male risk homozygotes and reduced fractional anisotropy on DTI (a sign of impaired white matter integrity) was exhibited in the right inferior fronto-occipital fasciculus by male risk homozygotes only. These findings pointed to a sex-specific gene effect within a right fronto-temporo-occipital circuit that has been implicated in ASD. A subsequent study found increased fMRI measured activation in the right inferior frontal and right medial temporal gyrus during language performance in healthy risk homozygotes at the rs2710102 and rs779475 SNPs, respectively (Whalley et al., 2011). Finally, Scott-Van Zeeland and others reported on associations between common CNTNAP2 variation and fMRI activation in two samples (Scott-Van Zeeland et al., 2010). These researchers first genotyped 16 children with ASD and 16 typically developing controls at the rs2710102 SNP and found increased medial prefrontal cortex activation during a reward-processing task in risk carriers, regardless of diagnosis. Functional connectivity analysis, measuring correlated activity with medial prefrontal cortex, indicated that while non-risk homozygotes exhibited a left-lateralized pattern of medial prefrontal cortex connectivity, risk carriers activated a diffuse, bilateral set of frontal and temporal regions. In a separate cohort of 39 typically developing children, the risk allele was further associated with reduced long-range connectivity between frontal, temporal and occipital regions, and increased local connectivity between left and right frontal cortex (Scott-Van Zeeland et al., 2010).

As would be anticipated, the aforementioned imaging-genetics research examining neural effects of neurexin superfamily genes has indicated that genetic variation in genes linked to ASD likely confer illness risk through their influence on structure and function within cortical networks involved in socio-communicative behaviors. Further, genes associated with ASD, have been associated with other neuropsychiatric disorders, as well as intellectual disability. It is now well established that the same genetic lesion can lead to different behavioral and cognitive phenotypes, even within the same family (Blackwood et al., 2001). One advantage of imaging-genetics is that the effects of a risk gene can be mapped more consistently onto neural circuitry that may confer vulnerability across different disorders. In the case of $\mathrm{Nr} \times n 1$ variation, altered frontal white matter volume, and secondary effects on frontal connectivity, may contribute to vulnerability for ASD and schizophrenia (Voineskos et al., 2011); disorders that share prominent abnormalities with respect to frontal lobe structure, activity, and frontal lobe mediated behaviors (Ameis et al., 2011; Radua et al., 2011; Voineskos et al., 2011). Similarly, CNTNAP2 variation may contribute to vulnerability for ASD and specific language impairment through influence on gray and white matter structure, activation and connectivity within a broad fronto-temporooccipital network involved in visuo-spatial and language functions (Catani and Thiebaut de Schotten, 2008; Philippi et al., 2009). As common genetic variations are found in healthy populations, they are clearly not sufficient to cause psychiatric disturbance, however, their effects may be accentuated by other genetic and environmental risk factors that together augment risk for ASD. The disrupted-in-schizophrenia (DISC1) gene (chromosome 1q42) is an example of a susceptibility locus for major mental illness that could potentially act as an additive genetic risk factor in ASD. The potential role for DISC1 in risk for mental illness was first identified based on a balanced chromosomal $\mathrm{t}(1 ; 11)$ translocation that disrupted the DISC1 protein sequence, and segregated in a highly significant manner with schizophrenia, bipolar disorder, and major depression, in a large and unique Scottish family (Millar et al., 2000; Blackwood et al., 2001). Subsequently, genomewide screening found CNVs affecting DISC1 in a boy with ASD (Williams et al., 2009), and two brothers with ASD and mental retardation (Crepel et al., 2010). DISC1 variants have also been implicated in ASD by family-based association studies of Finnish and Chinese Han families ascertained for ASD (Kilpinen et al., 2008; Zheng et al., 2011). The DISC1 gene encodes an intracellular scaffolding protein that interacts with proteins involved in 
regulation of early brain development, including neural proliferation and migration, synapse formation and maintenance (Mao et al., 2009; Ayhan et al., 2011; Brandon and Sawa, 2011). A recent study of DISC1 function in an animal model identified two discrete pathways whereby DISC1 interactions with different proteins contributed to distinct neurodevelopmental processes, including dendritic development, and neuronal positioning (Kang et al., 2011). Imaging-genetics studies have indicated that DISC1 variants influence cortical/hippocampal structure (Callicott et al., 2005; Di Giorgio et al., 2008; Szeszko et al., 2008; Brandon and Sawa, 2011; Brauns et al., 2011), and white matter integrity (Sprooten et al., 2011) in healthy adults. Of particular relevance to our discussion of ASD, is a longitudinal imaging-genetics study of 255 typically developing children and adolescents that found an association between common DISC1 variation (in rs6675281 and rs821616) and age-related rates of cortical thickness change within frontal and temporal cortex (Raznahan et al., 2011). Interestingly, a recent study indicated that DISC1 variation might increase risk for psychiatric illness through epistatic interactions with other genes within the DISC1 interactome (Kang et al., 2011). The DISC1 example may then provide a helpful model for how the same gene can confer risk for multiple psychiatric disorders based on the timing and location of additive risk effects and their discrete impact on the developing brain.

\section{GENES THAT AFFECT NEURAL SIGNALING AND THEIR THERAPEUTIC IMPLICATIONS \\ Gene variants influencing neuropeptide regulation}

A number of genes involved in neural signaling may have implications for ASD pathogenesis and available therapeutics. The oxytocin receptor (OXTR, chromosome 3p25) gene is one such example. The OXTR gene encodes the receptor protein for oxytocin. Oxytocin is a neuropeptide with significant importance for regulation of social cognition and behavior (Meyer-Lindenberg et al., 2011). High levels of plasma oxytocin have been associated with prosocial behavior. In contrast, low peripheral oxytocin levels have been found in individuals with ASD (Green et al., 2001; Meyer-Lindenberg et al., 2011). The OXTR gene has been implicated in ASD based on a number of positive association studies with common variants in OXTR and a rare deletion for OXTR that was found in an autistic proband and his mother (Wu et al., 2005; Lauritsen et al., 2006; Jacob et al., 2007; Gregory et al., 2009). The brain structural/functional, and behavioral effects associated with the ASD-implicated OXTR rs53576A SNP have recently been examined in a large sample of healthy adults $(n=212)$. In this study, an allele-load dependent association was found for reduced hypothalamus volume in healthy rs53576A risk allele carriers. An allele-load dependent effect was also found for increased right amygdala volume in male risk carriers only. Additionally, risk homozygotes exhibited decreased amygdala activity and increased amygdala-hypothalamus coupling during face processing. Risk homozygotes also had the lowest scores on reward dependence for the tridimensional personality questionnaire (TPQ), a measure of prosocial temperament. Finally, lower reward dependence scores were associated with increased amygdala and decreased hypothalamus volumes (Tost et al., 2010). Studies of another common OXTR variant (rs2254298), associated with ASD, have also demonstrated associations between OXTR risk alleles and altered amygdala volume (Inoue et al., 2010; Furman et al., 2011). Arginine vasopressin is an oxytocin related neuropeptide with similar importance for social regulation (Meyer-Lindenberg et al., 2011). Two of three polymorphic microsatellite repeats in the $5^{\prime}$ flanking region of the arginine vasopressin receptor 1A gene (AVPR1A; chromosome $12 \mathrm{q}$ ) have alleles featuring overtransmission (334and 340-bp RS3 alleles) and under transmission (312-bp allele of RS1) in ASD (Wassink et al., 2004; Meyer-Lindenberg et al., 2011). Interestingly, common variation at AVPR1A has been associated with differential activity of the amygdala during face processing (Meyer-Lindenberg et al., 2009). Although the specific effects of OXTR and AVPR1A variation on oxytocin and arginine vasopressin levels in the brain remain unclear, current data suggests that variation at these sites plays an important role in shaping social circuitry that has been linked to ASD impairments.

\section{Therapeutic implications related to oxytocin system research}

Neuroscience research examining the effects of oxytocin in the brain has fueled excitement about the potential use of oxytocin as a therapeutic agent in ASD. Neuroimaging studies have indicated that oxytocin administration promotes prosocial effects in healthy controls that seem to be mediated through altered limbic circuit activation in response to social stimuli (Gamer et al., 2010; Meyer-Lindenberg et al., 2011). Preliminary evidence from small randomized control trials has indicated that oxytocin treatment by intranasal administration or infusion may improve repetitive behaviors and social cognition in ASD (Hollander et al., 2003, 2007; Guastella et al., 2010). A number of clinical trials are currently underway to further examine the therapeutic utility and safety of oxytocin as a treatment in ASD (http://clinicaltrials.gov). Translational successes with oxytocin have also fueled preliminary candidate gene research that has found a positive association between CD38, a transmembrane protein involved in oxytocin secretion, in ASD (Munesue et al., 2010). Therefore, neuroscience research has been a critical element for the validation of oxytocin as a novel agent with considerable therapeutic potential in ASD.

\section{Gene variants influencing neurotransmitters and neurotrophic factors}

A small number of additional preliminary studies that have examined genes that code for signaling proteins, implicated in ASD, warrant brief discussion in this section. Monoamine neurotransmitters (serotonin, dopamine, and norepinephrine) have been implicated in a number of psychiatric disorders, including ASD (Lam et al., 2006). In particular, platelet hyperserotonemia (Lam et al., 2006), serotonin receptor abnormalities (Hollander et al., 2000; Hranilovic et al., 2007), and abnormal brain serotonin synthesis (Murphy et al., 2006) in ASD point to altered serotonin regulation. Monoamine oxidase A (MAOA) metabolizes monoamines. A VNTR polymorphism in the promoter region of the X-chromosome linked MAOA gene results in a highly active (MAOA-H) and less active (MAOA-L) allele (Chugani et al., 1997). Imaging-genetics studies have associated healthy $M A O A-L$ allele carriers with altered structure and function within limbic structures (Scharinger et al., 2011). Candidate gene examination has indicated that the MAOA-L VNTR polymorphism may be 
preferentially transmitted in ASD (Yoo et al., 2009). The MAOA-L allele has been associated with increased symptom severity in ASD (Cohen et al., 2003). Recently, Davis et al. (2008) found an association between the MAOA- $L$ VNTR polymorphism and increased cortical brain volume in male children with ASD. The serotonin transporter regulates brain serotonin levels, a neurotransmitter that plays an important role in brain growth (Raznahan et al., 2009a). A common polymorphism involving a variable number of tandem repeats in the $5^{\prime}$ promoter region (5HTTLPR) of the serotonin transporter gene (SLC6A4) results in a short or long allele. The 5HTTLPR short allele is associated with reduced gene transcription (Yirmiya et al., 2002; Cohen et al., 2003), and altered structure and activity within social circuitry in healthy controls (Heils et al., 1996). A recent meta-analysis of candidate gene studies that examined 5HTTLPR in ASD failed to find an overall association (Huang and Santangelo, 2008). However, Wassink et al. (2007) recently found an association between the 5HTTLPR short allele and increased cortical gray matter volume in young boys with ASD (aged 2-4 years). Another report found no association between brain structure and the 5HTTLPR short allele in older individuals with ASD. The brain-derived neurotrophic factor $(B D N F)$ is involved in neurogenesis, cortical lamination, and synaptic plasticity (Binder and Scharfman, 2004). Intracellular packaging and secretion of BDNF is altered by a common functional non-synonymous SNP within the $5^{\prime}$ region of the gene (BDNFval66met). Links between this SNP and ASD are limited to small association and candidate gene studies with mixed results (Philippe et al., 2002; Nishimura et al., 2007; Cheng et al., 2009). Evidence of altered peripheral BDNF levels in ASD, and increased forebrain $B D N F$ levels in autistic versus control brain, on postmortem examination, have been found (Perry et al., 2001). A recent imaging-genetics study of the neural effects associated with the BDNFval66met polymorphism in 41 participants with ASD and 30 controls ( $\sim 12-64$ years) found a group by genotype interaction in their sample. Healthy BDNF met allele carriers exhibited decreased cortical volume and surface area in cingulate and frontal regions compared to $B D N F$ val homozygotes, while met allele carriers with ASD exhibited greater volume in these regions compared to their BDNF val homozygote counterparts (Raznahan et al., 2009b). While evidence for the role of genetic variation in MAOA, SLC6A4, and BDNF remains equivocal in ASD, preliminary imaging-genetics findings suggest that common variation in these genes could have a role in determining brain structure in ASD. Based on these findings, continued consideration of the potential additive risk effects conferred by genetic factors affecting these neurotransmitter and neurotrophin systems is warranted in ASD.

\section{EXAMINING BRAIN EFFECTS IN GENETIC DISORDERS RELEVANT TO SYNDROMIC AUTISM}

Imaging studies of genetic syndromes with high rates of ASD, provide added information regarding the way risk genes confer neural risk for illness symptoms. Fragile X syndrome is the most common inherited form of mental retardation, affecting 1 in 4000 males and 1 in 8000 females (Gaspar et al., 2003). Features of the fragile $\mathrm{X}$ syndrome include: a long narrow face, macroorchidism, large protruding ears, mild to moderate mental retardation, language acquisition delay, hyperactivity, anxiety, seizures, and autisticlike behaviors (i.e., repetitive behavior, decreased attention, and poor eye contact; Hatton et al., 2006). Up to $30 \%$ of males with fragile $\mathrm{X}$ syndrome have co-morbid autism (Fatemi and Folsom, 2011). The fragile $\mathrm{X}$ syndrome is caused by a trinucleotide expansion ( $>200$ CGG repeats) in the X-linked fragile $\mathrm{X}$ mental retardation 1 (FMR1) gene, resulting in hypermethylation and gene silencing (Hatton et al., 2006). Gene silencing interferes with fragile $\mathrm{X}$ mental retardation protein (FMRP) production. FMRP is otherwise synthesized at synapses in response to synaptic activation (Fatemi and Folsom, 2011). In FMR1 KO mouse brain, and post-mortem human studies of fragile $\mathrm{X}$ syndrome, increased density of long, thin, and immature dendritic spines found in cortex, cerebellum, and hippocampus, has indicated that FMRP plays an important role in regulating normal synaptic development/maturation (Weiler et al., 1997). Two neuroimaging studies that have reported on a large sample, including male children with: idiopathic ASD $(n=63)$, fragile X syndrome $(n=52)$, developmental delay $(n=19)$, and typically developing controls ( $n=31$; Irwin et al., 2000), provide insights into whether fragile X syndrome and idiopathic ASD share brain-based phenotypes. First, Hazlett and colleagues found caudate and amygdala volumes differentiated between IQ matched children with fragile X syndrome and idiopathic ASD. Caudate enlargement was found in fragile $\mathrm{X}$ syndrome children with and without autism, but only idiopathic ASD children exhibited amygdala enlargement (Hazlett et al., 2009). A more recent report on this sample, indicated that fragile X syndrome and idiopathic ASD children could be further differentiated based on opposing volumetric abnormalities in frontal and temporal cortex (i.e., increased volume in ASD, and decreased volume in fragile X syndrome with or without co-morbid ASD). Interestingly, multivariate analysis indicated that brain structure in children with idiopathic ASD was more similar to typically developing children and children with developmental delay than to children with fragile $\mathrm{X}$ syndrome, either with or without co-morbid autism (Hoeft et al., 2011). Other findings extend previous results to adults, indicating that increased volume within frontal, parietal, cingulate, caudate, and cerebellar regions differentiates between fragile $\mathrm{X}$ syndrome and ASD, while a pattern involving increased frontal and temporal volume is more characteristic of ASD (Wilson et al., 2009). The aforementioned neuroimaging studies examining fragile X syndrome and idiopathic ASD seem to indicate that brain-based phenotypes in these disorders differ more than they overlap.

The 22q11.2 microdeletion syndrome is the most common human deletion syndrome (Goodship et al., 1998). The syndrome is characterized by congenital heart malformations, palatal abnormalities, facial dysmorphology, learning difficulties, and developmental delay (Shprintzen, 2000a,b). Risk for psychiatric comorbidity is high, especially for schizophrenia in young adults (Chow et al., 1994). The prevalence of ASD in 22q11.2 deletion syndrome ranges from 20 to 50\% (Vorstman et al., 2006; Antshel et al., 2007; Niklasson et al., 2009). The 22q11.2 deletion syndrome affects approximately 45 genes (Philip and Bassett, 2011). Neuroimaging studies in 22q11.2 deletion syndrome have implicated: reduced cerebellar volume (van Amelsvoort et al., 2004), 
increased amygdala volume (Kates et al., 2006), decreased fusiform gyrus activity during face processing, and altered patterns of neural response to emotionally expressive faces (Andersson et al., 2008); findings that overlap with neuroimaging results in ASD. A preliminary study has found that children with the 22q11.2 deletion syndrome with co-morbid autism have more pronounced amygdala enlargement than affected children without autism (Antshel et al., 2007).

Tuberous sclerosis complex is a genetic neurocutaneous syndrome, caused by mutations inTSC1 or TSC2 genes. Protein products associated with TSC1 and TSC2 are critical for regulating cell proliferation and differentiation. The tuberous sclerosis complex is a multi-system disorder characterized by the development of benign tumors that can occur in any organ system, including the brain, where tubers are found in cortical and subcortical brain regions (Tomasoni and Mondino, 2011). High rates of mental retardation, epilepsy and ASD are found in individuals with tuberous sclerosis complex (Asato and Hardan, 2004). Although some neuroimaging studies have found an association between the presence of tubers within the temporal lobe and autistic symptoms in tuberous sclerosis complex (Bolton and Griffiths, 1997; Seri et al., 1999; Bolton et al., 2002), this association is not consistently found (Doherty et al., 2005; Wong and Khong, 2006). A recent DTI study examined the microstructural integrity of the corpus callosum white matter in 40 patients with tuberous sclerosis complex and 29 matched controls. In this study, tuberous sclerosis complex patients exhibited signs of altered white matter microstructure, compared to controls, however, pronounced reductions in white matter integrity were specific to tuberous sclerosis complex patients with ASD (Peters et al., 2012).

Thus far, a limited number of studies that have compared children with syndromic autism to idiopathic autism seem to implicate neural differences between these disorders, rather than similarities. However, disruption affecting the amygdala and temporal lobe may be one important site of overlap, where lesions confer risk for ASD symptoms. Future studies examining individuals with a genetic lesion without autism versus those with autism, in conjunction with comparison of an idiopathic ASD, and relevant control group will be best suited to furthering our understanding of how a highly penetrant genetic lesion may contribute to increased risk for ASD. Refined genetic mapping to stratify participants with identified genetic syndromes according to specific gene involvement, could narrow genetic heterogeneity further, and be of added benefit to this line of neuroimaging research.

\section{CONCLUSIONS}

Imaging-genetics studies applied to ASD have begun to characterize pathways whereby common genetic variation in typically developing individuals confers risk for symptoms through influence on structure, activity, and connectivity within relevant neural circuits. Neurexin superfamily genes may increase symptom risk through altered frontal white matter structure and connectivity (Antshel et al., 2007), and disruption of fronto-temporooccipital circuits involved in visuo-spatial and language processing (Voineskos et al., 2011). Oxytocin and arginine vasopressin receptor genes may influence neuropeptide signaling and socioemotional functioning through altered structure and function within amygdala-hypothalamic circuitry (Tan et al., 2010). While these findings are promising, the imaging-genetics field in ASD is still very much in its infancy. Through further characterization of the effects of common ASD-implicated variants on the brain, the repository of known genetic pathways that influence risk for ASD can be expanded. Future research efforts aimed at capitalizing on the extraordinary promise of imaging-genetics research in ASD will benefit from some key methodological advances. First, integration of a multimodal approach to neuroimaging, in addition to more detailed behavioral characterization for relevant brain-behavior correlations, will enhance efforts to elucidate the relationships between genes, altered neural circuits and behavior. Sophisticated methods used to examine gene-gene and gene-environment interactions will be needed to characterize the complex genetic factors contributing to ASD, such studies will require larger sample sizes relative to those examined to date. Further, in a common disorder influenced by rare genetic mutations, reverse phenotyping (Schulze and McMahon, 2004; Philippe et al., 2008), where brain-based phenotypes are characterized in groups with overlapping rare genetic abnormalities, revealed through deep gene sequencing, may be another promising approach for mapping the effects of ASD risk genes. Further, a developmental approach where the time-dependent effects of genetic variants influencing altered neurodevelopment are studied longitudinally, particularly in the first years of life, will be essential to the translational success of imaging-genetics in ASD. Finally, a promising and relatively novel approach is the combination of transcranial magnetic stimulation with electroencephalography or fMRI. This combination can provide new insights into brain function, with high temporal resolution, and can measure altered plasticity in neuropsychiatric disorders, which may be a useful neural phenotype for genetic mapping (Pascual-Leone et al., 2011).

Advancements in the widespread ability to acquire noninvasive, high quality brain imaging scans, quickly, and during natural sleep, has made it feasible to undertake neuroimaging of infants at high genetic risk for ASD. Further, preliminary longitudinal neuroimaging results have indicated that brain differences in ASD may be detectable prior to the development of ASD symptoms (Wolff et al., 2012). These exciting findings suggest that early neuroimaging biomarkers of risk patterns for ASD expression may be within reach. Using the imaging-genetics approach, infants at high genetic risk for ASD may be further stratified according to brain-based phenotypes associated with discrete genetic risk factors that signal vulnerability for developing ASD symptoms, based on altered brain development. This stratification could then cue opportunities for customized therapeutic interventions that could be implemented early, while the brain is highly plastic and the full potential to normalize brain development and optimize outcome may be realized. For such translational advancement to take place, the availability of genetically based animal models will be crucial to create opportunities to: (i) study the effects of specific genes, or gene systems on brain development, in a controlled setting, using high resolution imaging, and phenotyping to validate brain-behavior relationships, and (ii) test novel therapeutics and 
their effects on brain development and behavior. A developmental approach to imaging-genetics research in ASD may move the promise of this field into the clinical domain and toward delivery of targeted therapeutic options to affected individuals and their families.

\section{REFERENCES}

Alarcon, M., Abrahams, B. S., Stone, J. L., Duvall, J. A., Perederiy, J. V., Bomar, J. M., Sebat, J., Wigler, M., Martin, C. L., Ledbetter, D. H., Nelson, S. F., Cantor, R. M., and Geschwind, D. H. (2008). Linkage, association, and gene-expression analyses identify CNTNAP2 as an autismsusceptibility gene. Am. J. Hum. Genet. 82, 150-159.

Ameis, S. H., Fan, J., Rockel, C., Voineskos, A. N., Lobaugh, N. J., Soorya, L., Wang, A. T., Hollander, E., and Anagnostou, E. (2011). Impaired structural connectivity of socio-emotional circuits in autism spectrum disorders: a diffusion tensor imaging study. PLoS ONE 6, e28044. doi:10.1371/journal.pone.0028044

Andersson, F., Glaser, B., Spiridon, M., Debbane, M., Vuilleumier, P., and Eliez, S. (2008). Impaired activation of face processing networks revealed by functional magnetic resonance imaging in 22q11.2 deletion syndrome. Biol. Psychiatry 63, 49-57.

Antshel, K. M., Aneja, A., Strunge, L., Peebles, J., Fremont, W. P., Stallone, K., Abdulsabur, N., Higgins, A. M., Shprintzen, R. J., and Kates, W. R. (2007). Autistic spectrum disorders in velo-cardio facial syndrome (22q11.2 deletion). J. Autism Dev. Disord. 37, 1776-1786.

Arking, D. E., Cutler, D. J., Brune, C. W., Teslovich, T. M., West, K., Ikeda, M., Rea, A., Guy, M., Lin, S., Cook, E. H., and Chakravarti, A. (2008). A common genetic variant in the neurexin superfamily member CNTNAP2 increases familial risk of autism. Am. J. Hum. Genet. 82, 160-164.

Asato, M. R., and Hardan, A. Y. (2004). Neuropsychiatric problems in tuberous sclerosis complex. J. Child Neurol. 19, 241-249.

Ayhan, Y., Abazyan, B., Nomura, J., Kim, R., Ladenheim, B., Krasnova, I. N., Sawa, A., Margolis, R. L., Cadet, J. L., Mori, S., Vogel, M. W., Ross, C. A., and Pletnikov, M. V. (2011). Differential effects of prenatal and postnatal expressions of mutant human DISC1 on neurobehavioral phenotypes in transgenic mice: evidence for neurodevelopmental origin of major psychiatric disorders. Mol. Psychiatry 16, 293-306.

Bakkaloglu, B., O’Roak, B. J., Louvi, A., Gupta, A. R., Abelson, J. F., Morgan, T. M., Chawarska, K., Klin, A., ErcanSencicek, A. G., Stillman, A. A., Tanriover, G., Abrahams, B. S., Duvall, J. A., Robbins, E. M., Geschwind, D. H., Biederer, T., Gunel, M., Lifton, R. P., and State, M. W. (2008). Molecular cytogenetic analysis and resequencing of contactin associated protein-like 2 in autism spectrum disorders. Am. J. Hum. Genet. 82, 165-173.

Bangash, M. A., Park, J. M., Melnikova, T., Wang, D., Jeon, S. K., Lee, D., Syeda, S., Kim, J., Kouser, M. Schwartz, J., Cui, Y., Zhao, X., Speed, H. E., Kee, S. E., Tu, J. C., Hu, J. H., Petralia, R. S., Linden, D. J., Powell, C. M., Savonenko, A., Xiao, B., and Worley, P. F. (2011). Enhanced polyubiquitination of Shank3 and NMDA receptor in a mouse model of autism. Cell 145, 758-772.

Barnea-Goraly, N., Lotspeich, L. J., and Reiss, A. L. (2010). Similar white matter aberrations in children with autism and their unaffected siblings: a diffusion tensor imaging study using tract-based spatial statistics. Arch. Gen. Psychiatry 67, 1052-1060.

Bauman, M. L. (2010). Medical comorbidities in autism: challenges to diagnosis and treatment. Neurotherapeutics 7, 320-327.

Belmonte, M. K., Allen, G., BeckelMitchener, A., Boulanger, L. M. Carper, R. A., and Webb, S. J. (2004). Autism and abnormal development of brain connectivity. J. Neurosci. 24, 9228-9231.

Binder, D. K., and Scharfman, H. E. (2004). Brain-derived neurotrophic factor. Growth Factors 22, 123-131.

Blackwood, D. H., Fordyce, A., Walker, M. T., St Clair, D. M., Porteous, D. J., and Muir, W. J. (2001). Schizophrenia and affective disorders cosegregation with a translocation at chromosome 1q42 that directly disrupts brain-expressed genes: clinical and P300 findings in a family. Am. J. Hum. Genet. 69, 428-433.

Bolton, P. F., and Griffiths, P. D. (1997). Association of tuberous sclerosis of temporal lobes with autism and atypical autism. Lancet 349, 392-395.

\section{ACKNOWLEDGMENTS}

Stephanie H. Ameis is supported by the Autism Research Training Program, funded by the Canadian Institutes of Health Research. The authors report no biomedical financial interests or potential conflicts of interest.

Bolton, P. F., Park, R. J., Higgins, J. N., Griffiths, P. D., and Pickles, A. (2002). Neuro-epileptic determinants of autism spectrum disorders in tuberous sclerosis complex. Brain 125, 1247-1255.

Brandon, N. J., and Sawa, A. (2011). Linking neurodevelopmental and synaptic theories of mental illness through DISC1. Nat. Rev. Neurosci. $12,707-722$.

Brauns, S., Gollub, R. L., Roffman, J. L., Yendiki, A., Ho, B. C., Wassink, T. H., Heinz, A., and Ehrlich, S. (2011). DISC1 is associated with cortical thickness and neural efficiency. Neuroimage 57, 1591-1600.

Callicott, J. H., Straub, R. E., Pezawas, L., Egan, M. F., Mattay, V. S., Hariri, A. R., Verchinski, B. A., Meyer-Lindenberg, A., Balkissoon, R., Kolachana, B., Goldberg, T. E., and Weinberger, D. R. (2005). Variation in DISC1 affects hippocampa structure and function and increases risk for schizophrenia. Proc. Natl. Acad. Sci. U.S.A. 102, 8627-8632.

Catani, M., and Thiebaut de Schotten, M. (2008). A diffusion tensor imaging tractography atlas for virtual in vivo dissections. Cortex 44, 1105-1132.

Cheng, L., Ge, Q., Xiao, P., Sun, B., Ke, X., Bai, Y., and Lu, Z. (2009). Association study between BDNF gene polymorphisms and autism by threedimensional gel-based microarray. Int. J. Mol. Sci. 10, 2487-2500.

Chow, E. W., Bassett, A. S., and Weksberg, R. (1994). Velo-cardio-facial syndrome and psychotic disorders: implications for psychiatric genetics. Am. J. Med. Genet. 54, 107-112.

Chugani, D. C., Muzik, O., Rothermel, R., Behen, M., Chakraborty, P., Mangner, T., da Silva, E. A., and Chugani, H. T. (1997). Altered serotonin synthesis in the dentatothalamocortical pathway in autistic boys. Ann. Neurol. 42, 666-669.

Cohen, I. L., Liu, X., Schutz, C., White, B. N., Jenkins, E. C., Brown, W. T., and Holden, J. J. (2003). Association of autism severity with a monoamine oxidase A functional polymorphism. Clin. Genet. 64, 190-197.

Courchesne, E., Mouton, P. R., Calhoun, M. E., Semendeferi, K., AhrensBarbeau, C., Hallet, M. J., Barnes,
C. C., and Pierce, K. (2011). Neuron number and size in prefrontal cortex of children with autism. JAMA 306, 2001-2010.

Crepel, A., Breckpot, J., Fryns, J. P., De la Marche, W., Steyaert, J., Devriendt, K., and Peeters, H. (2010). DISC1 duplication in two brothers with autism and mild mental retardation. Clin. Genet. 77, 389-394.

Davis, L. K., Hazlett, H. C., Librant, A. L., Nopoulos, P., Sheffield, V. C., Piven, J., and Wassink, T. H. (2008). Cortical enlargement in autism is associated with a functional VNTR in the monoamine oxidase A gene. Am. J. Med. Genet. B Neuropsychiatr. Genet. 147B, 1145-1151.

Di Giorgio, A., Blasi, G., Sambataro, F., Rampino, A., Papazacharias, A., Gambi, F., Romano, R., Caforio, G., Rizzo, M., Latorre, V., Popolizio, T., Kolachana, B., Callicott, J. H., Nardini, M., Weinberger, D. R., and Bertolino, A. (2008). Association of the SerCys DISC1 polymorphism with human hippocampal formation gray matter and function during memory encoding. Eur. J. Neurosci. 28, 2129-2136.

Di Martino, A., Ross, K., Uddin, L. Q., Sklar, A. B., Castellanos, F. X., and Milham, M. P. (2009). Functional brain correlates of social and nonsocial processes in autism spectrum disorders: an activation likelihood estimation meta-analysis. Biol. Psychiatry 65, 63-74.

Doherty, C. G., YoungPoussaint, T., Erdag, N., and Thiele, E. A. (2005). Prognostic significance of tuber count and location in tuberous sclerosis complex. J. Child Neurol. 20, 837-841.

Enticott, P. G., Rinehart, N. J., Tonge, B. J., Bradshaw, J. L., and Fitzgerald, P. B. (2010). A preliminary transcranial magnetic stimulation study of cortical inhibition and excitability in high-functioning autism and Asperger disorder. Dev. Med. Child Neurol. 52, e179-e183.

Etherton, M. R., Blaiss, C. A., Powell, C. M., and Sudhof, T. C. (2009) Mouse neurexin-1alpha deletion causes correlated electrophysiological and behavioral changes consistent with cognitive impairments. Proc. Natl. Acad. Sci. U.S.A. 106, 17998-18003. 
Fatemi, S. H., and Folsom, T. D. (2011). The role of fragile $\mathrm{X}$ mental retardation protein in major mental disorders. Neuropharmacology 60, 1221-1226.

Fatemi, S. H., Reutiman, T. J., Folsom, T. D., and Thuras, P. D. (2009). $\mathrm{GABA}(\mathrm{A})$ receptor downregulation in brains of subjects with autism. J. Autism Dev. Disord. 39, 223-230.

First. (2000). American Psychiatric Association: Diagnostic and Statistical Manual of Mental Disorders 4th Edition. Washington: American Psychiatric Association.

Folstein, S., and Rutter, M. (1977). Infantile autism: a genetic study of 21 twin pairs. J. Child. Psychol. Psychiatry 18, 297-321.

Fombonne, E. (2001). Is there an epidemic of autism? Pediatrics 107, 411-412.

Furman, D. J., Chen, M. C., and Gotlib, I. H. (2011). Variant in oxytocin receptor gene is associated with amygdala volume. Psychoneuroendocrinology 36, 891-897.

Gamer, M., Zurowski, B., and Buchel, C. (2010). Different amygdala subregions mediate valence-related and attentional effects of oxytocin in humans. Proc. Natl. Acad. Sci. U.S.A. 107, 9400-9405.

Gaspar, P., Cases, O., and Maroteaux, L. (2003). The developmental role of serotonin: news from mouse molecular genetics. Nat. Rev. Neurosci. 4, 1002-1012.

Geschwind, D. H. (2011). Genetics of autism spectrum disorders. Trends Cogn. Sci. (Regul. Ed.) 15, 409-416.

Gilman, S. R., Iossifov, I., Levy, D., Ronemus, M., Wigler, M., and Vitkup, D. (2011). Rare de novo variants associated with autism implicate a large functional network of genes involved in formation and function of synapses. Neuron 70, 898-907.

Goodship, J., Cross, I., LiLing, J., and Wren, C. (1998). A population study of chromosome $22 \mathrm{q} 11$ deletions in infancy. Arch. Dis. Child. 79, 348-351.

Green, L., Fein, D., Modahl, C., Feinstein, C., Waterhouse, L., and Morris, M. (2001). Oxytocin and autistic disorder: alterations in peptide forms. Biol. Psychiatry 50, 609-613.

Gregory, S. G., Connelly, J. J., Towers, A. J., Johnson, J., Biscocho, D., Markunas, C. A., Lintas, C., Abramson, R. K., Wright, H. H., Ellis, P., Langford, C. F., Worley, G., Delong, G. R., Murphy, S. K., Cuccaro, M. L., Persico, A., and Pericak-Vance, M. A. (2009). Genomic and epigenetic evidence for oxytocin receptor deficiency in autism. BMC Med. 7, 62. doi:10.1186/1741-7015-7-62

Guastella, A. J., Einfeld, S. L., Gray, K. M., Rinehart, N. J., Tonge, B. J., Lambert, T. J., and Hickie, I. B. (2010). Intranasal oxytocin improves emotion recognition for youth with autism spectrum disorders. Biol. Psychiatry 67, 692-694.

Hadjikhani, N., Joseph, R. M., Snyder, J., Chabris, C. F., Clark, J., Steele, S., McGrath, L., Vangel, M., Aharon, I., Feczko, E., Harris, G. J., and TagerFlusberg, H. (2004). Activation of the fusiform gyrus when individuals with autism spectrum disorder view faces. Neuroimage 22, 1141-1150.

Hatton, D. D., Sideris, J., Skinner, M., Mankowski, J., Bailey, D. B. Jr., Roberts, J., and Mirrett, P. (2006). Autistic behavior in children with fragile X syndrome: prevalence, stability, and the impact of FMRP. Am. J. Med. Genet. A 140A: 1804-1813.

Hazlett, H. C., Poe, M. D., Lightbody, A. A., Gerig, G., Macfall, J. R., Ross, A. K., Provenzale, J., Martin, A., Reiss, A. L., and Piven, J. (2009). Teasing apart the heterogeneity of autism: same behavior, different brains in toddlers with fragile $\mathrm{X}$ syndrome and autism. J. Neurodev. Disord. 1, 81-90.

Heils, A., Teufel, A., Petri, S., Stober, G., Riederer, P., Bengel, D., and Lesch, K. P. (1996). Allelic variation of human serotonin transporter gene expression. J. Neurochem. 66, 2621-2624.

Herbert, M. R., Ziegler, D. A., Deutsch, C. K., O'Brien, L. M., Lange, N., Bakardjiev, A., Hodgson, J., Adrien, K. T., Steele, S., Makris, N., Kennedy, D., Harris, G. J., and Caviness, V. S. Jr. (2003). Dissociations of cerebral cortex, subcortical and cerebral white matter volumes in autistic boys. Brain 126, 1182-1192.

Hoeft, F., Walter, E., Lightbody, A. A., Hazlett, H. C., Chang, C., Piven, J., and Reiss, A. L. (2011). Neuroanatomical differences in toddler boys with fragile $\mathrm{x}$ syndrome and idiopathic autism. Arch. Gen. Psychiatry 68, 295-305.

Hollander, E., Bartz, J., Chaplin, W., Phillips, A., Sumner, J., Soorya, L., Anagnostou, E., and Wasserman, S. (2007). Oxytocin increases retention of social cognition in autism. Biol. Psychiatry 61, 498-503.

Hollander, E., Novotny, S., Allen, A., Aronowitz, B., Cartwright, C., and DeCaria, C. (2000). The relationship between repetitive behaviors and growth hormone response to sumatriptan challenge in adult autistic disorder. Neuropsychopharmacology 22, 163-167.
Hollander, E., Novotny, S., Hanratty, M. Yaffe, R., DeCaria, C. M., Aronowitz, B. R., and Mosovich, S. (2003). Oxytocin infusion reduces repetitive behaviors in adults with autistic and Asperger's disorders. Neuropsychopharmacology 28, 193-198.

Hranilovic, D., Bujas-Petkovic, Z. Vragovic, R., Vuk, T., Hock, K., and Jernej, B. (2007). Hyperserotonemia in adults with autistic disorder. $J$. Autism Dev. Disord. 37, 1934-1940.

Huang, C. H., and Santangelo, S. L. (2008). Autism and serotonin transporter gene polymorphisms: a systematic review and meta-analysis. Am. J. Med. Genet. B Neuropsychiatr. Genet. 147B, 903-913.

Hyde, K. L., Samson, F., Evans, A. C., and Mottron, L. (2010). Neuroanatomical differences in brain areas implicated in perceptual and other core features of autism revealed by cortical thickness analysis and voxelbased morphometry. Hum. Brain Марp. 31, 556-566.

Inoue, H., Yamasue, H., Tochigi, M., Abe, O., Liu, X., Kawamura, Y., Takei, K., Suga, M., Yamada, H., Rogers, M. A., Aoki, S., Sasaki, T., and Kasai, K. (2010). Association between the oxytocin receptor gene and amygdalar volume in healthy adults. Biol. Psychiatry 68, 1066-1072.

Irwin, S. A., Galvez, R., and Greenough, W. T. (2000). Dendritic spine structural anomalies in fragile-X mental retardation syndrome. Cereb. Cortex 10, 1038-1044.

Jacob, S., Brune, C. W., Carter, C. S., Leventhal, B. L., Lord, C., and Cook, E. H. Jr. (2007). Association of the oxytocin receptor gene (OXTR) in Caucasian children and adolescents with autism. Neurosci. Lett. 417, 6-9.

Jamain, S., Quach, H., Betancur, C., Rastam, M., Colineaux, C., Gillberg, I. C., Soderstrom, H., Giros, B., Leboyer, M., Gillberg, C., Bourgeron, T., and Paris Autism Research International Sibpair Study. (2003). Mutations of the X-linked genes encoding neuroligins NLGN3 and NLGN4 are associated with autism. Nat. Genet. 34, 27-29.

Just, M. A., Cherkassky, V. L., Keller, T. A., Kana, R. K., and Minshew, N. J. (2007). Functional and anatomical cortical underconnectivity in autism: evidence from an FMRI study of an executive function task and corpus callosum morphometry. Cereb. Cortex 17, 951-961.

Just, M. A., Cherkassky, V. L., Keller, T. A., and Minshew, N. J. (2004). Cortical activation and synchronization during sentence comprehension in high-functioning autism: evidence of underconnectivity. Brain 127, 1811-1821.

Kana, R. K., Keller, T. A., Cherkassky, V. L., Minshew, N. J., and Just, M. A. (2006). Sentence comprehension in autism: thinking in pictures with decreased functional connectivity. Brain 129, 2484-2493.

Kang, E., Burdick, K. E., Kim, J. Y., Duan, X., Guo, J. U., Sailor, K. A., Jung, D. E., Ganesan, S., Choi, S., Pradhan, D., Lu, B., Avramopoulos, D., Christian, K., Malhotra, A. K., Song, H., and Ming, G. L. (2011). Interaction between FEZ1 and DISC1 in regulation of neuronal development and risk for schizophrenia. Neuron 72, 559-571.

Kanner, L. (1971). Follow-up study of eleven autistic children originally reported in 1943. J. Autism Child. Schizophr. 1, 119-145.

Kates, W. R., Miller, A. M., Abdulsabur, N., Antshel, K. M., Conchelos, J., Fremont, W., and Roizen, N. (2006). Temporal lobe anatomy and psychiatric symptoms in velocardiofacial syndrome (22q11.2 deletion syndrome). J. Am. Acad. Child Adolesc. Psychiatry 45, 587-595.

Kennedy, D. P., and Courchesne, E. (2008). The intrinsic functional organization of the brain is altered in autism. Neuroimage 39, 1877-1885.

Kilpinen, H., Ylisaukko-Oja, T., Hennah, W., Palo, O. M., Varilo, T., Vanhala, R., Nieminen-von Wendt, T., von Wendt, L., Paunio, T., and Peltonen, L. (2008). Association of DISC1 with autism and Asperger syndrome. Mol. Psychiatry 13, 187-196.

Kim, H. G., Kishikawa, S., Higgins, A. W., Seong, I. S., Donovan, D. J., Shen, Y., Lally, E., Weiss, L. A., Najm, J., Kutsche, K., Descartes, M., Holt, L., Braddock, S., Troxell, R., Kaplan, L., Volkmar, F., Klin, A., Tsatsanis, K., Harris, D. J., Noens, I., Pauls, D. L., Daly, M. J., MacDonald, M. E., Morton, C. C., Quade, B. J., and Gusella, J. F. (2008). Disruption of neurexin 1 associated with autism spectrum disorder. Am. J. Hum. Genet. 82, 199-207.

Kirov, G., Rujescu, D., Ingason, A., Collier, D. A., O’Donovan, M. C., and Owen, M. J. (2009). Neurexin 1 (NRXN1) deletions in schizophrenia. Schizophr. Bull. 35, 851-854.

Kumar, A., Sundaram, S. K., Sivaswamy, L., Behen, M. E., Makki, M. I., Ager, J., Janisse, J., Chugani, H. T., and Chugani, D. C. (2010). Alterations in frontal lobe tracts and corpus callosum in young children with autism 
spectrum disorder. Cereb. Cortex 20, 2103-2113.

Lam, K. S., Aman, M. G., and Arnold, L. E. (2006). Neurochemical correlates of autistic disorder: a review of the literature. Res. Dev. Disabil. 27, 254-289.

Laumonnier, F., Bonnet-Brilhault, F., Gomot, M., Blanc, R., David, A., Moizard, M. P., Raynaud, M., Ronce, N., Lemonnier, E., Calvas, P., Laudier, B., Chelly, J., Fryns, J. P., Ropers, H. H., Hamel, B. C., Andres, C., Barthélémy, C., Moraine, C., and Briault, S. (2004). X-linked mental retardation and autism are associated with a mutation in the NLGN4 gene, a member of the neuroligin family. Am. J. Hum. Genet. 74, 552-557.

Lauritsen, M. B., Als, T. D., Dahl, H. A., Flint, T. J., Wang, A. G., Vang, M., Kruse, T. A., Ewald, H., and Mors, O. (2006). A genome-wide search for alleles and haplotypes associated with autism and related pervasive developmental disorders on the Faroe Islands. Mol. Psychiatry 11, 37-46.

Levy, D., Ronemus, M., Yamrom, B., Lee, Y. H., Leotta, A., Kendall, J., Marks, S., Lakshmi, B., Pai, D., Ye, K., Buja, A., Krieger, A., Yoon, S., Troge, J., Rodgers, L., Iossifov, I., and Wigler, M. (2011). Rare de novo and transmitted copy-number variation in autistic spectrum disorders. Neuron 70, 886-897.

Mao, Y., Ge, X., Frank, C. L., Madison, J. M., Koehler, A. N., Doud, M. K., Tassa, C., Berry, E. M., Soda, T., Singh, K. K., Biechele, T., Petryshen, T. L., Moon, R. T., Haggarty, S. J., and Tsai, L. H. (2009). Disrupted in schizophrenia 1 regulates neuronal progenitor proliferation via modulation of GSK3beta/beta-catenin signaling. Cell 136, 1017-1031.

Marshall, C. R., Noor, A., Vincent, J. B., Lionel, A. C., Feuk, L., Skaug, J., Shago, M., Moessner, R., Pinto, D., Ren, Y., Thiruvahindrapduram, B., Fiebig, A., Schreiber, S., Friedman, J., Ketelaars, C. E., Vos, Y. J., Ficicioglu, C., Kirkpatrick, S., Nicolson, R., Sloman, L., Summers, A., Gibbons, C. A., Teebi, A., Chitayat, D., Weksberg, R., Thompson, A., Vardy, C., Crosbie, V., Luscombe, S., Baatjes, R., Zwaigenbaum, L., Roberts, W., Fernandez, B., Szatmari, P., and Scherer, S. W. (2008). Structural variation of chromosomes in autism spectrum disorder. Am. J. Hum. Genet. 82, 477-488.

Marshall, C. R., and Scherer, S. W. (2012). Detection and characterization of copy number variation in autism spectrum disorder. Methods Mol. Biol. 838, 115-135.

Meyer-Lindenberg, A., Domes, G., Kirsch, P., and Heinrichs, M. (2011). Oxytocin and vasopressin in the human brain: social neuropeptides for translational medicine. Nat. Rev. Neurosci. 12, 524-538.

Meyer-Lindenberg, A., Kolachana, B., Gold, B., Olsh, A., Nicodemus, K. K., Mattay, V., Dean, M., and Weinberger, D. R. (2009). Genetic variants in AVPR1A linked to autism predict amygdala activation and personality traits in healthy humans. Mol. Psychiatry 14, 968-975.

Meyer-Lindenberg, A., and Weinberger, D. R. (2006). Intermediate phenotypes and genetic mechanisms of psychiatric disorders. Nat. Rev. Neurosci. 7, 818-827.

Millar, J. K., Wilson-Annan, J. C., Anderson, S., Christie, S., Taylor, M. S., Semple, C. A., Devon, R. S., St Clair, D. M., Muir, W. J., Blackwood, D. H., and Porteous, D. J. (2000). Disruption of two novel genes by a translocation co-segregating with schizophrenia. Hum. Mol. Genet. 9, 1415-1423.

Munesue, T., Yokoyama, S., Nakamura, K., Anitha, A., Yamada, K., Hayashi, K., Asaka, T., Liu, H. X., Jin, D., Koizumi, K., Islam, M. S., Huang, J. J., Ma, W. J., Kim, U. H., Kim, S. J., Park, K., Kim, D., Kikuchi, M., Ono, Y., Nakatani, H., Suda, S., Miyachi, T., Hirai, H., Salmina, A., Pichugina, Y. A., Soumarokov, A. A., Takei, N., Mori, N., Tsujii, M., Sugiyama, T., Yagi, K., Yamagishi, M., Sasaki, T., Yamasue, H., Kato, N., Hashimoto, R., Taniike, M., Hayashi, Y., Hamada, J., Suzuki, S., Ooi, A., Noda, M., Kamiyama, Y., Kido, M. A., Lopatina, O., Hashii, M., Amina, S., Malavasi, F., Huang, E. J., Zhang, J., Shimizu, N., Yoshikawa, T., Matsushima, A., Minabe, Y., and Higashida, H. (2010). Two genetic variants of CD38 in subjects with autism spectrum disorder and controls. Neurosci. Res. 67, 181-191.

Murphy, D. G., Daly, E., Schmitz, N., Toal, F., Murphy, K., Curran, S., Erlandsson, K., Eersels, J., Kerwin, R., Ell, P., and Travis, M. (2006). Cortical serotonin 5-HT2A receptor binding and social communication in adults with Asperger's syndrome: an in vivo SPECT study. Am. J. Psychiatry 163, 934-936.

Niklasson, L., Rasmussen, P., Oskarsdottir, S., and Gillberg, C. (2009). Autism, ADHD, mental retardation and behavior problems in 100 individuals with 22q11 deletion syndrome. Res. Dev. Disabil. 30, 763-773.

Nishimura, K., Nakamura, K., Anitha, A., Yamada, K., Tsujii, M., Iwayama, Y., Hattori, E., Toyota, T., Takei, N., Miyachi, T., Iwata, Y., Suzuki, K., Matsuzaki, H., Kawai, M., Sekine, Y., Tsuchiya, K., Sugihara, G., Suda, S. Ouchi, Y., Sugiyama, T., Yoshikawa, T., and Mori, N. (2007). Genetic analyses of the brain-derived neurotrophic factor (BDNF) gene in autism. Biochem. Biophys. Res. Commun. 356, 200-206.

Nordahl, C. W., Scholz, R., Yang, X., Buonocore, M. H., Simon, T., Rogers, S., and Amaral, D. G. (2012). Increased rate of amygdala growth in children aged 2 to 4 years with autism spectrum disorders: a longitudinal study. Arch. Gen. Psychiatry 69, 53-61.

Pascual-Leone, A., Freitas, C., Oberman, L., Horvath, J. C., Halko, M., Eldaief, M., Bashir, S., Vernet, M., Shafi, M., Westover, B., VahabzadehHagh, A. M., and Rotenberg, A. (2011). Characterizing brain cortical plasticity and network dynamics across the age-span in health and disease with TMS-EEG and TMS-fMRI. Brain Topogr. 24, 302-315.

Penagarikano, O., Abrahams, B. S., Herman, E. I., Winden, K. D., Gdalyahu, A., Dong, H., Sonnenblick, L. I., Gruver, R., Almajano, J., Bragin, A., Golshani, P., Trachtenberg, J. T., Peles, E., and Geschwind, D. H. (2011). Absence of CNTNAP2 leads to epilepsy, neuronal migration abnormalities, and core autismrelated deficits. Cell 147, 235-246.

Perry, E. K., Lee, M. L., Martin-Ruiz, C. M., Court, J. A., Volsen, S. G., Merrit, J., Folly, E., Iversen, P. E., Bauman, M. L., Perry, R. H., and Wenk, G. L. (2001). Cholinergic activity in autism: abnormalities in the cerebral cortex and basal forebrain. Am. J. Psychiatry 158, 1058-1066.

Peters, J. M., Sahin, M., Vogel-Farley, V. K., Jeste, S. S., Nelson, C. A. III, Gregas, M. C., Prabhu, S. P., Scherrer, B., and Warfield, S. K. (2012). Loss of white matter microstructural integrity is associated with adverse neurological outcome in tuberous sclerosis complex. Acad. Radiol. 19, 17-25.

Philip, N., and Bassett, A. (2011). Cognitive, behavioural and psychiatric phenotype in 22q11.2 deletion syndrome. Behav. Genet. 41, 403-412.

Philippe, A., Boddaert, N., VaivreDouret, L., Robel, L., DanonBoileau, L., Malan, V., de Blois, M. C., Heron, D., Colleaux, L., Golse, B., Zilbovicius, M., and Munnich, A.
(2008). Neurobehavioral profile and brain imaging study of the $22 \mathrm{q} 13.3$ deletion syndrome in childhood. Pediatrics 122, e376-e382.

Philippe, A., Guilloud-Bataille, M., Martinez, M., Gillberg, C., Rastam, M., Sponheim, E., Coleman, M., Zappella, M., Aschauer, H., Penet, C., Feingold, J., Brice, A., Leboyer, M., and Paris Autism Research International Sibpair Study. (2002). Analysis of ten candidate genes in autism by association and linkage. Am. J. Med. Genet. 114, 125-128.

Philippi, C. L., Mehta, S., Grabowski, T., Adolphs, R., and Rudrauf, D. (2009). Damage to association fiber tracts impairs recognition of the facial expression of emotion. J. Neurosci. 29, 15089-15099.

Pierce, K., Haist, F., Sedaghat, F., and Courchesne, E. (2004). The brain response to personally familiar faces in autism: findings of fusiform activity and beyond. Brain 127, 2703-2716.

Pierce, K., Muller, R. A., Ambrose, J., Allen, G., and Courchesne, E. (2001). Face processing occurs outside the fusiform 'face area' in autism: evidence from functional MRI. Brain 124, 2059-2073.

Pinto, D., Pagnamenta, A. T., Klei, L., Anney, R., Merico, D., Regan, R., Conroy, J., Magalhaes, T. R., Correia, C., Abrahams, B. S., Almeida, J., Bacchelli, E., Bader, G. D., Bailey, A. J., Baird, G., Battaglia, A., Berney, T., Bolshakova, N., Bölte, S., Bolton, P. F., Bourgeron, T., Brennan, S., Brian, J., Bryson, S. E., Carson, A. R., Casallo, G., Casey, J., Chung, B. H., Cochrane, L., Corsello, C. Crawford, E. L., Crossett, A., Cytrynbaum, C., Dawson, G., de Jonge, M., Delorme, R., Drmic, I., Duketis, E., Duque, F., Estes, A., Farrar, P., Fernandez, B. A., Folstein, S. E., Fombonne, E., Freitag, C. M., Gilbert, J., Gillberg, C., Glessner, J. T., Goldberg, J., Green, A., Green, J., Guter, S. J., Hakonarson, H., Heron, E. A., Hill, M., Holt, R., Howe, J. L., Hughes, G., Hus, V., Igliozzi, R., Kim, C., Klauck, S. M., Kolevzon, A., Korvatska, O., Kustanovich, V., Lajonchere, C. M., Lamb, J. A., Laskawiec, M., Leboyer, M., Le Couteur, A., Leventhal, B. L., Lionel, A. C., Liu, X. Q., Lord, C., Lotspeich, L., Lund, S. C., Maestrini, E., Mahoney, W., Mantoulan, C., Marshall, C. R., McConachie, H., McDougle, C. J., McGrath, J., McMahon, W. M., Merikangas, A., Migita, O., Minshew, N. J., Mirza, G. K., Munson, J., Nelson, S. F., Noakes, C., Noor, A., Nygren, G., Oliveira, G., Papanikolaou, K., Parr, J. R., Parrini, 
B., Paton, T., Pickles, A., Pilorge, M., Piven, J., Ponting, C. P., Posey, D. J., Poustka, A., Poustka, F., Prasad, A., Ragoussis, J., Renshaw, K., Rickaby, J., Roberts, W., Roeder, K., Roge, B., Rutter, M. L., Bierut, L. J., Rice, J. P., Salt, J., Sansom, K., Sato, D., Segurado, R., Sequeira, A. F., Senman, L., Shah, N., Sheffield, V. C., Soorya, L., Sousa, I., Stein, O., Sykes, N., Stoppioni, V., Strawbridge, C., Tancredi, R., Tansey, K., Thiruvahindrapduram, B., Thompson, A. P., Thomson, S., Tryfon, A., Tsiantis, J., Van Engeland, H., Vincent, J. B., Volkmar, F., Wallace, S., Wang, K., Wang, Z., Wassink, T. H., Webber, C., Weksberg, R., Wing, K., Wittemeyer, K., Wood, S., Wu, J., Yaspan, B. L., Zurawiecki, D., Zwaigenbaum, L., Buxbaum, J. D., Cantor, R. M., Cook, E. H., Coon, H., Cuccaro, M. L., Devlin, B., Ennis, S., Gallagher, L., Geschwind, D. H., Gill, M., Haines, J. L., Hallmayer, J., Miller, J., Monaco, A. P., Nurnberger, J. I. Jr., Paterson, A. D., Pericak-Vance, M. A., Schellenberg, G. D., Szatmari, P., Vicente, A. M., Vieland, V. J., Wijsman, E. M., Scherer, S. W., Sutcliffe, J. S., and Betancur, C. (2010). Functional impact of global rare copy number variation in autism spectrum disorders. Nature 466, 368-372.

Pugliese, L., Catani, M., Ameis, S., Dell'Acqua, F., Thiebaut de Schotten, M., Murphy, C., Robertson, D., Deeley, Q., Daly, E., and Murphy, D. G. (2009). The anatomy of extended limbic pathways in Asperger syndrome: a preliminary diffusion tensor imaging tractography study. Neuroimage 47, 427-434.

Radua, J., Via, E., Catani, M., and Mataix-Cols, D. (2011). Voxelbased meta-analysis of regional white-matter volume differences in autism spectrum disorder versus healthy controls. Psychol. Med. 41, 1539-1550.

Raznahan, A., Lee, Y., Long, R., Greenstein, D., Clasen, L., Addington, A., Rapoport, J. L., and Giedd, J. N. (2011). Common functional polymorphisms of DISC1 and cortical maturation in typically developing children and adolescents. Mol. Psychiatry 16, 917-926.

Raznahan, A., Pugliese, L., Barker, G. J., Daly, E., Powell, J., Bolton, P. F., and Murphy, D. G. (2009a). Serotonin transporter genotype and neuroanatomy in autism spectrum disorders. Psychiatr. Genet. 19, 147-150.

Raznahan, A., Toro, R., Proitsi, P., Powell, J., Paus, T., F Bolton, P., and
Murphy, D. G. (2009b). A functional polymorphism of the brain derived neurotrophic factor gene and cortical anatomy in autism spectrum disorder. J. Neurodev. Disord. 1 , 215-223.

Rujescu, D., Ingason, A., Cichon, S., Pietilainen, O. P., Barnes, M. R., Toulopoulou, T., Picchioni, M., Vassos, E., Ettinger, U., Bramon, E., Murray, R., Ruggeri, M., Tosato, S., Bonetto, C., Steinberg, S., Sigurdsson, E., Sigmundsson, T., Petursson, H., Gylfason, A., Olason, P. I., Hardarsson, G., Jonsdottir, G. A., Gustafsson, O., Fossdal, R., Giegling, I., Möller, H. J., Hartmann, A. M., Hoffmann, P., Crombie, C., Fraser, G., Walker, N., Lonnqvist, J., Suvisaari, J., Tuulio-Henriksson, A., Djurovic, S., Melle, I., Andreassen, O. A., Hansen, T., Werge, T., Kiemeney, L. A., Franke, B., Veltman, J., BuizerVoskamp, J. E., GROUP Investigators, Sabatti, C., Ophoff, R. A., Rietschel, M., Nöthen, M. M., Stefansson, K., Peltonen, L., St Clair, D., Stefansson, H., and Collier, D. A. (2009). Disruption of the neurexin 1 gene is associated with schizophrenia. Hum. Mol. Genet. 18, 988-996.

Schaaf, C. P., and Zoghbi, H. Y. (2011). Solving the autism puzzle a few pieces at a time. Neuron 70, 806-808.

Scharinger, C., Rabl, U., Pezawas, L., and Kasper, S. (2011). The genetic blueprint of major depressive disorder: contributions of imaging genetics studies. World J. Biol. Psychiatry 12, 474-488.

Schultz, R. T., Gauthier, I., Klin, A., Fulbright, R. K., Anderson, A. W., Volkmar, F., Skudlarski, P., Lacadie, C., Cohen, D. J., and Gore, J. C. (2000). Abnormal ventral temporal cortical activity during face discrimination among individuals with autism and Asperger syndrome. Arch. Gen. Psychiatry 57, 331-340.

Schulze, T. G., and McMahon, F. J. (2004). Defining the phenotype in human genetic studies: forward genetics and reverse phenotyping. Hum. Hered. 58, 131-138.

Schumann, C. M., Bloss, C. S., Barnes, C. C., Wideman, G. M., Carper, R. A., Akshoomoff, N., Pierce, K., Hagler, D., Schork, N., Lord, C., and Courchesne, E. (2010). Longitudinal magnetic resonance imaging study of cortical development through early childhood in autism. J. Neurosci. 30, 4419-4427.

Scott-Van Zeeland, A. A., Abrahams, B. S., Alvarez-Retuerto, A. I., Sonnenblick, L. I., Rudie, J. D., Ghahremani, D., Mumford, J. A., Poldrack, R. A., Dapretto, M., Geschwind, D.
H., and Bookheimer, S. Y. (2010). Altered functional connectivity in frontal lobe circuits is associated with variation in the autism risk gene CNTNAP2. Sci. Transl. Med. 2 , $56 \mathrm{ra} 80$.

Sebat, J., Lakshmi, B., Malhotra, D. Troge, J., Lese-Martin, C., Walsh, T., Yamrom, B., Yoon, S., Krasnitz, A., Kendall, J., Leotta, A., Pai, D., Zhang, R., Lee, Y. H., Hicks, J., Spence, S. J., Lee, A. T., Puura, K., Lehtimäki, T., Ledbetter, D., Gregersen, P. K., Bregman, J., Sutcliffe, J. S., Jobanputra, V., Chung, W., Warburton, D., King, M. C., Skuse, D., Geschwind, D. H., Gilliam, T. C., Ye, K., and Wigler, M. (2007). Strong association of de novo copy number mutations with autism. Science 316, 445-449.

Seri, S., Cerquiglini, A., Pisani, F., and Curatolo, P. (1999). Autism in tuberous sclerosis: evoked potential evidence for a deficit in auditory sensory processing. Clin. Neurophysiol. 110, 1825-1830.

Shprintzen, R. J. (2000a). Velocardiofacial syndrome. Otolaryngol. Clin. North Am. 33, 1217-1240.

Shprintzen, R. J. (2000b). Velo-cardiofacial syndrome: a distinctive behavioral phenotype. Ment. Retard Dev. Disabil. Res. Rev. 6, 142-147.

Shukla, D. K., Keehn, B., and Muller, R. A. (2011). Tract-specific analyses of diffusion tensor imaging show widespread white matter compromise in autism spectrum disorder. J. Child. Psychol. Psychiatry 52, 286-295.

Sprooten, E., Sussmann, J. E., Moorhead, T. W., Whalley, H. C., FfrenchConstant, C., Blumberg, H. P., Bastin, M. E., Hall, J., Lawrie, S. M., and McIntosh, A. M. (2011). Association of white matter integrity with genetic variation in an exonic DISC1 SNP. Mol. Psychiatry 16, 685.

State, M. W., and Levitt, P. (2011). The conundrums of understanding genetic risks for autism spectrum disorders. Nat. Neurosci. 14, 1499-1506.

Strauss, K. A., Puffenberger, E. G., Huentelman, M. J., Gottlieb, S., Dobrin, S. E., Parod, J. M., Stephan, D. A., and Morton, D. H. (2006). Recessive symptomatic focal epilepsy and mutant contactinassociated protein-like 2. N. Engl. J. Med. 354, 1370-1377.

Sudhof, T. C. (2008). Neuroligins and neurexins link synaptic function to cognitive disease. Nature 455, 903-911.

Szatmari, P. (2000). The classification of autism, Asperger's syndrome, and pervasive developmental disorder. Can. J. Psychiatry 45, 731-738.
Szatmari, P. (2011). New recommendations on autism spectrum disorder. BMJ 342, d2456.

Szatmari, P., Paterson, A. D., Zwaigenbaum, L., Roberts, W., Brian, J., Liu, X. Q., Vincent, J. B., Skaug, J. L., Thompson, A. P., Senman, L., Feuk, L., Qian, C., Bryson, S. E., Jones, M. B., Marshall, C. R., Scherer, S. W., Vieland, V. J., Bartlett, C., Mangin, L. V., Goedken, R., Segre, A., PericakVance, M. A., Cuccaro, M. L., Gilbert, J. R., Wright, H. H., Abramson, R. K., Betancur, C., Bourgeron, T., Gillberg, C., Leboyer, M., Buxbaum, J. D., Davis, K. L., Hollander, E., Silverman, J. M., Hallmayer, J., Lotspeich, L., Sutcliffe, J. S., Haines, J. L., Folstein, S. E., Piven, J., Wassink, T. H., Sheffield, V., Geschwind, D. H., Bucan, M., Brown, W. T., Cantor, R. M., Constantino, J. N., Gilliam, T. C., Herbert, M., Lajonchere, C., Ledbetter, D. H., Lese-Martin, C., Miller, J., Nelson, S., Samango-Sprouse, C. A., Spence, S., State, M., Tanzi, R. E., Coon, H., Dawson, G., Devlin, B., Estes, A., Flodman, P., Klei, L., McMahon, W. M., Minshew, N., Munson, J., Korvatska, E., Rodier, P. M., Schellenberg, G. D., Smith, M., Spence, M. A., Stodgell, C., Tepper, P. G., Wijsman, E. M., Yu, C. E., Rogé, B., Mantoulan, C., Wittemeyer, K., Poustka, A., Felder, B., Klauck, S. M., Schuster, C., Poustka, F., Bölte, S., Feineis-Matthews, S., Herbrecht, E., Schmötzer, G., Tsiantis, J., Papanikolaou, K., Maestrini, E., Bacchelli, E., Blasi, F., Carone, S., Toma, C., Van Engeland, H., de Jonge, M., Kemner, C., Koop, F., Langemeijer, M., Hijmans, C., Staal, W. G., Baird, G., Bolton, P. F., Rutter, M. L., Weisblatt, E., Green, J., Aldred, C., Wilkinson, J. A., Pickles, A., Le Couteur, A., Berney, T., McConachie, H., Bailey, A. J., Francis, K., Honeyman, G., Hutchinson, A., Parr, J. R., Wallace, S., Monaco, A. P., Barnby, G., Kobayashi, K., Lamb, J. A., Sousa, I., Sykes, N., Cook, E. H., Guter, S. J., Leventhal, B. L., Salt, J., Lord, C., Corsello, C., Hus, V., Weeks, D. E., Volkmar, F., Tauber, M., Fombonne, E., Shih, A., and Meyer, K. J. (2007). Mapping autism risk loci using genetic linkage and chromosomal rearrangements. Nat. Genet. 39, 319-328.

Szeszko, P. R., Hodgkinson, C. A., Robinson, D. G., Derosse, P., Bilder, R. M., Lencz, T., Burdick, K. E., Napolitano, B., Betensky, J. D., Kane, J. M., Goldman, D., and Malhotra, A. K. (2008). DISC1 is associated with prefrontal cortical gray matter and positive symptoms 
in schizophrenia. Biol. Psychol. 79, 103-110.

Tan, G. C., Doke, T. F., Ashburner, J., Wood, N. W., and Frackowiak, R. S. (2010). Normal variation in fronto-occipital circuitry and cerebellar structure with an autismassociated polymorphism of CNTNAP2. Neuroimage 53, 1030-1042.

Tomasoni, R., and Mondino, A. (2011). The tuberous sclerosis complex: balancing proliferation and survival. Biochem. Soc. Trans. 39, 466-471.

Tost, H., Kolachana, B., Hakimi, S., Lemaitre, H., Verchinski, B. A., Mattay, V. S., Weinberger, D. R., and Meyer-Lindenberg, A. (2010). A common allele in the oxytocin receptor gene (OXTR) impacts prosocial temperament and human hypothalamic-limbic structure and function. Proc. Natl. Acad. Sci. U.S.A. 107, 13936-13941.

van Amelsvoort, T., Daly, E., Henry, J., Robertson, D., Ng, V., Owen, M., Murphy, K. C., and Murphy, D. G. (2004). Brain anatomy in adults with velocardiofacial syndrome with and without schizophrenia: preliminary results of a structural magnetic resonance imaging study. Arch. Gen. Psychiatry 61, 1085-1096.

Vernes, S. C., Newbury, D. F., Abrahams, B. S., Winchester, L., Nicod, J., Groszer, M., Alarcón, M., Oliver, P. L., Davies, K. E., Geschwind, D. H., Monaco, A. P., and Fisher, S. E. (2008). A functional genetic link between distinct developmental language disorders. N. Engl. J. Med. 359, 2337-2345.

Voineagu, I., Wang, X., Johnston, P., Lowe, J. K., Tian, Y., Horvath, S., Mill, J., Cantor, R. M., Blencowe, B. J., and Geschwind, D. H. (2011). Transcriptomic analysis of autistic brain reveals convergent molecular pathology. Nature 474, 380-384.

Voineskos, A. N., Lett, T. A., Lerch, J. P., Tiwari, A. K., Ameis, S. H., Rajji, T. K., Müller, D. J., Mulsant, B. H., and Kennedy, J. L (2011). Neurexin-1 and frontal lobe white matter: an overlapping intermediate phenotype for schizophrenia and autism spectrum disorders. PLoS ONE 6: e20982. doi:10.1371/journal.pone.0020982

Vorstman, J. A., Morcus, M. E., Duijff, S. N., Klaassen, P. W., Heineman-de Boer, J. A., Beemer, F. A., Swaab, H., Kahn, R. S., and van Engeland, H. (2006). The 22q11.2 deletion in children: high rate of autistic disorders and early onset of psychotic symptoms. J. Am. Acad. Child Adolesc. Psychiatry 45, 1104-1113.
Walsh, T., McClellan, J. M., McCarthy, S. E., Addington, A. M., Pierce, S. B., Cooper, G. M., Nord, A. S., Kusenda, M., Malhotra, D., Bhandari, A., Stray, S. M., Rippey, C. F., Roccanova, P., Makarov, V., Lakshmi, B., Findling, R. L., Sikich, L., Stromberg, T., Merriman, B., Gogtay, N., Butler, P., Eckstrand, K., Noory, L., Gochman, P., Long, R., Chen, Z., Davis, S., Baker, C., Eichler, E. E., Meltzer, P. S., Nelson, S. F., Singleton, A. B., Lee, M. K., Rapoport, J. L., King, M. C., and Sebat, J. (2008). Rare structural variants disrupt multiple genes in neurodevelopmental pathways in schizophrenia. Science 320, 539-543.

Wang, K., Zhang, H., Ma, D., Bucan, M., Glessner, J. T., Abrahams, B. S., Salyakina, D., Imielinski, M., Bradfield, J. P., Sleiman, P. M., Kim, C. E., Hou, C., Frackelton, E., Chiavacci, R., Takahashi, N., Sakurai, T., Rappaport, E., Lajonchere, C. M., Munson, J., Estes, A., Korvatska, O., Piven, J., Sonnenblick, L. I., Alvarez Retuerto, A. I., Herman, E. I., Dong, H., Hutman, T., Sigman, M., Ozonoff, S., Klin, A., Owley, T., Sweeney, J. A., Brune, C. W., Cantor, R. M., Bernier, R., Gilbert, J. R., Cuccaro, M. L., McMahon, W. M., Miller, J., State, M. W., Wassink, T. H., Coon, H., Levy, S. E., Schultz, R. T., Nurnberger, J. I., Haines, J. L., Sutcliffe, J. S., Cook, E. H., Minshew, N. J., Buxbaum, J. D., Dawson, G., Grant, S. F., Geschwind, D. H., PericakVance, M. A., Schellenberg, G. D., and Hakonarson, H. (2009). Common genetic variants on $5 \mathrm{p} 14.1$ associate with autism spectrum disorders. Nature 459, 528-533.

Wassink, T. H., Hazlett, H. C., Epping, E. A., Arndt, S., Dager, S. R., Schellenberg, G. D., Dawson, G., and Piven, J. (2007). Cerebral cortical gray matter overgrowth and functional variation of the serotonin transporter gene in autism. Arch. Gen. Psychiatry 64, 709-717.

Wassink, T. H., Piven, J., Vieland, V. J., Pietila, J., Goedken, R. J., Folstein, S. E., and Sheffield, V. C. (2004). Examination of AVPR1a as an autism susceptibility gene. Mol. Psychiatry 9, 968-972.

Weiler, I. J., Irwin, S. A., Klintsova, A. Y., Spencer, C. M., Brazelton, A. D., Miyashiro, K., Comery, T. A., Patel, B., Eberwine, J., and Greenough, W. T. (1997). Fragile $\mathrm{X}$ mental retardation protein is translated near synapses in response to neurotransmitter activation. Proc. Natl. Acad. Sci. U.S.A. 94, 5395-5400.
Weiss, L. A., Arking, D. E., Daly, M. J., and Chakravarti, A. (2009). A genome-wide linkage and association scan reveals novel loci for autism. Nature 461, 802-808.

Whalley, H. C., O'Connell, G., Sussmann, J. E., Peel, A., Stanfield, A. C., Hayiou-Thomas, M. E., Johnstone, E. C., Lawrie, S. M., McIntosh, A. M., and Hall, J. (2011). Genetic variation in CNTNAP2 alters brain function during linguistic processing in healthy individuals. Am. J. Med. Genet. B Neuropsychiatr. Genet. 156B, 941-948.

Wicker, B., Fonlupt, P., Hubert, B. Tardif, C., Gepner, B., and Deruelle, C. (2008). Abnormal cerebral effective connectivity during explicit emotional processing in adults with autism spectrum disorder. Soc. Cogn. Affect. Neurosci. 3, 135-143.

Williams, J. M., Beck, T. F., Pearson, D. M., Proud, M. B., Cheung, S. W., and Scott, D. A. (2009). A 1q42 deletion involving DISC1, DISC2, and TSNAX in an autism spectrum disorder. Am. J. Med. Genet. A 149A, 1758-1762.

Wilson, L. B., Tregellas, J. R., Hagerman, R. J., Rogers, S. J., and Rojas, D. C. (2009). A voxel-based morphometry comparison of regional gray matter between fragile $\mathrm{X}$ syndrome and autism. Psychiatry Res. 174, 138-145.

Wolff, J. J., Gu, H., Gerig, G., Elison, J. T. Styner, M., Gouttard, S., Botteron, K. N., Dager, S. R., Dawson, G., Estes, A. M., Evans, A. C., Hazlett, H. C., Kostopoulos, P., McKinstry, R. C., Paterson, S. J., Schultz, R. T., Zwaigenbaum, L., and Piven, J. (2012). Differences in white matter fiber tract development present from 6 to 24 months in infants with autism. Am. J. Psychiatry. doi: 10.1176/appi.ajp.2011.11091447. [Epub ahead of print].

Wong, V., and Khong, P. L. (2006). Tuberous sclerosis complex: correlation of magnetic resonance imaging (MRI) findings with comorbidities. J. Child Neurol. 21, 99-105.

Wu, S., Jia, M., Ruan, Y., Liu, J., Guo, Y., Shuang, M., Gong, X., Zhang, Y., Yang, X., and Zhang, D. (2005). Positive association of the oxytocin receptor gene (OXTR) with autism in the Chinese Han population. Biol. Psychiatry 58, 74-77.

Yan, J., Noltner, K., Feng, J., Li, W. Schroer, R., Skinner, C., Zeng, W., Schwartz, C. E., and Sommer, S. S. (2008). Neurexin 1alpha structural variants associated with autism. Neurosci. Lett. 438, 368-370.
Yan, J., Oliveira, G., Coutinho, A., Yang, C., Feng, J., Katz, C., Sram, J., Bockholt, A., Jones, I. R., Craddock, N., Cook, E. H. Jr., Vicente, A., and Sommer, S. S. (2005). Analysis of the neuroligin 3 and 4 genes in autism and other neuropsychiatric patients. Mol. Psychiatry 10, 329-332.

Yirmiya, N., Pilowsky, T., Tidhar, S., Nemanov, L., Altmark, L., and Ebstein, R. P. (2002). Family-based and population study of a functional promoter-region monoamine oxidase A polymorphism in autism: possible association with IQ. Am. J. Med. Genet. 114, 284-287.

Yoo, H. J., Lee, S. K., Park, M., Cho, I. H., Hyun, S. H., Lee, J. C., Yang, S. Y., and Kim, S. A. (2009). Family- and population-based association studies of monoamine oxidase $A$ and autism spectrum disorders in Korean. Neurosci. Res. 63, 172-176.

Zheng, F., Wang, L., Jia, M., Yue, W., Ruan, Y., Lu, T., Liu, J., Li, J., and Zhang, D. (2011). Evidence for association between disruptedin-schizophrenia 1 (DISC1) gene polymorphisms and autism in Chinese Han population: a familybased association study. Behav. Brain Funct. 7, 14.

Zikopoulos, B., and Barbas, H. (2010). Changes in prefrontal axons may disrupt the network in autism. J. Neurosci. 30, 14595-14609.

Conflict of Interest Statement: The authors declare that the research was conducted in the absence of any commercial or financial relationships that could be construed as a potential conflict of interest.

Received: 01 March 2012; paper pending published: 22 March 2012; accepted: 23 April 2012; published online: 15 May 2012.

Citation: Ameis SH and Szatmari $P$ (2012) Imaging-genetics in autism spectrum disorder: advances, translational impact, and future directions. Front. Psychiatry 3:46. doi: 10.3389/fpsyt.2012.00046

This article was submitted to Frontiers in Neuropsychiatric Imaging and Stimulation, a specialty of Frontiers in Psychiatry. Copyright (c) 2012 Ameis and Szatmari. This is an open-access article distributed under the terms of the Creative Commons Attribution Non Commercial License, which permits non-commercial use, distribution, and reproduction in other forums, provided the original authors and source are credited. 